\title{
LA CONCIENCIA MEDIÁTICA
}

\section{THE MEDIA AWARENESS}

Juan Ignacio Hernáiz Blázquez: Profesor titular de Historia de la Comunicación de la Facultad de Ciencias de la Información. Universidad Complutense de Madrid (España) jignaciohb@ccinf.ucm.es

\section{CURRÍCULUM VITAE}

Profesor de la Facultad de Ciencias de la Información de la Universidad Complutense de Madrid, desde finales de los años 70. Además es articulista, conferenciante y profesor en cursos y másteres.

\section{RESUMEN}

La conciencia mediática no es ni la conciencia escrupulosa ni la ausencia de la misma, es decir, ni la bondad ni la maldad, o sea, ni lo positivo social ni lo negativo. La cultura mediática no tiene conciencia del pecado religioso, no hay ofensa a Dios, pues éste es la televisión, a no ser que se apague el receptor. La conciencia mediática es la de la mayoría de la sociedad, puesto que santos y asesinos son dos minorías muy reducidas, místicos y criminales son extremos muy pequeños.

La conciencia mediática es ambigua, ilógica, absurda, contradictoria, indefinida, antirradical, moderada, equilibrada, desapasionada, antimaniquea, antifanática y centrista en política, religión y filosofía, por lo tanto, no es ni de derechas ni de izquierdas, ni religiosa ni atea, ni idealista ni materialista. La televisión democrática, como decía N.A.Chomsky, sustituye el miedo de las dictaduras fascista y comunista, 
por la manipulación. La conciencia mediática no tiene la cultura de los libros ni la incultura analfabeta, posee la cultura del disco, del cassette, de la televisión, de la radio, de la prensa, del ordenador y del vídeo.

\title{
PALABRAS CLAVE
}

Conciencia - Mediático - Comunicación

\begin{abstract}
The media conscience is neither the scrupulous conscience nor the absence of the same one, that is to say, neither the kindness nor the evilness, or, neither the social positive thing nor the negative thing. The media culture does not have conscience of the religious sin, there is no offence to God, since this one is the television, unless the equipment is switched off. The media conscience is that of the majority of the society, since saints and assassins are two very limited minorities, mystics and criminals are very small extremes.
\end{abstract}

The media conscience is ambiguous, illogical, absurd, contradictory, indefinite, antiradical, moderate, balanced, lacking in passion, antimanichean, antifanatical and centrist in politics, religion and philosophy, therefore, is neither on the right wing not on democratic television, as N.A.Chomsky said, replaces the fascist and communist dictatorships fear with the manipulation. The media conscience has neither the culture of the books nor the illiterate lack of refinement, possesses the culture of the record, of the cassette, of the television, of the radio, of the press, of the computer and of the video. 


\section{KEY WORDS}

Conscience - Media - Communication

\section{ÍNDICE}

1. La conciencia mediática

2. Internet

3. G.W.F.Hegel

4. Las clases sociales

5. La libertad

6. La lógica

7. I.Kant

8. Bibliografía

9. Filmografía

10. Webgrafía

\section{TEXTO:}

\section{La conciencia mediática}

P.Nipkow (1.860 - 1.940) y H.R.Hatt, en Alemania en el año 1.884; J.Berzelius (1.779 1.848) sueco, en el año 1.817, con el descubrimiento del selenio; S.Rodda y G.Henri de Francia, en el año 1.934, creando el sistema SECAM, luego W.Bruch hará el PAL; J.L.Baird (1.888 - 1.946), en Inglaterra el 10 de Septiembre de 1.929, en la B.B.C., con la ley del 1 de Enero de 1.927; V.K.Zworykyn (1.889) ruso en Norteamérica, Ch.F.Jenkins, en U.S.A. en el año 1.953, W.S.Stephenson y G.W.Walton, en el año 
1.923, en la B.T.C. y la R.C.A., en el año 1.931, en la C.B.S., en el año 1.941, en la N.B.C., en el año 1.939, inventan la televisión que es la creación técnica productora de la conciencia mediática de la humanidad, pero no la única, también está Internet, el teléfono, la radio, el cine, la fotografía, el telégrafo, el disco, el cassette o M.C., el disco compacto o C.D., el magnetofón, el vídeo o V.H.S., Beta, el D.V.D., el UBS y el disquette. Pero no pueden competir con la televisión en la capacidad de alienación de las personas. La alienación en el sentido de G.W.F.Hegel (Hegel, 1.807), como desdoblamiento de la conciencia, el amo y el esclavo, la dialéctica o fenomenología del espíritu, donde una parte de la sensibilidad está dominada por la otra, el inconsciente sobre el consciente K.Marx (Marx, 1.873) trasladó ese concepto a la economía, con la lucha de clases sociales y S.Freud (Maynard, 1987) a la sicología. La conciencia mediática es una cuestión estética o hipertextual, aunque también ética o metatextual y técnica o patatextual, esquema 2 de otro libro mío (Hernáiz, 1.999: 34 y 35).

El 22 de Marzo de 1.935, en Alemania, es la primera emisión experimental, durante los juegos olímpicos. T.Turner, en el año 1.950, inventa en la C.N.N., la televisión por cable. Por satélite se creó en el año 1.975. La televisión digital Sony empezó experimentálmente, en el año 1.985. S.Aronowitz (Sartori, 2.003: 12 y ss) ha estudiado la sociología de la televisión, es decir, la influencia del medio en las clases sociales, sexos y generaciones, o sea, el condicionamiento de la pequeña pantalla en ricos y pobres, hombres y mujeres, viejos y jóvenes. H.Bloom (Bloom, 1.995) escribe que la enseñanza es una forma de espectáculo, por lo tanto, es óbice que el mayor espectáculo de todos los tiempos, es la televisión, lo cual nos lleva lógicamente a que, la educación de los niños, en, la actualidad, es mayoritariamente, la pequeña pantalla. C.Paglia (Sartori, 2.003: 29 y ss) dice que, la televisión, es como el rosario católico, inventado por Sto.Domingo de Guzmán, nacido en Caleruega (Burgos), convence a fuerza de repetir las veinticuatro horas del día, en todas las cadenas, insistiendo con los espots publicitarios, aunque los anuncios cambien estéticamente, 
mantienen sicológicamente el sistema económico de la sociedad del consumo o del bienestar.

La W.T.B.S. y la H.B.O. son emisoras norteamericanas por cable, la W.N.E.T. en N.York y la W.G.B.H. en Boston también. La P.B.S. es pública, desde el año 1.967. La I.T.V. inglesa es privada, desde el 30 de Julio de 1.954. La R.T.Belga, empieza en el año 1.953, igual que la danesa, la austriaca en el año 1.955, lo mismo que la luxemburguesa y la noruega, la sueca en el año 1.956, la holandesa en el año 1.960, la O.R.T.F. francesa el 27 de Junio de 1.964, la R.T.A. argelina el 9 de diciembre de 1.967, la A.R.D. alemana aunque había empezado el 22 de Marzo de 1.935, recomenzó el en el año 1.961, como la Z.D.F., la S.S.R. suiza el 24 de Febrero de 1.931, la R.A.I. italiana el 27 de Febrero de 1.936, la israelí el 17 de Marzo de 1.965, la R.T.P. portuguesa el 18 de Octubre de 1.955, la N.H.K. japonesa en el año 1.950. Hasta L.Althusser (Althusser, 1.969) que analiza la escuela, como soporte ideológico del estado, siempre se había pensado que, la mayor influencia en los niños, era el colegio, por encima de la pandilla de amigos y de la familia, los tres grupos primarios de referencia, ahora es la televisión. Esdecir, lo que los padres enseñen a los hijos, los maestros a los alumnos y los amigos, juntas las tres influencias, son menores que la pequeña pantalla. D.D.Kerckhove (Ornia, 1.991: 13) habla del spindoctoring o ingeniero de opinión, cuyo trabajo consiste en dar efecto televisivo.

En Burgos, en el año 1.938, como capital del bando nacional de la guerra civil, experimentalmente, a toda España, en el año 1.949, por fin se crea TVE 1, el 21 de Octubre de 1.956, TVE 2 el 1 de Enero de 1.965, la privada Antena 3 el 25 de Enero de 1.990, la privada Tele 5 el 1 de Abril de 1.990, la privada Canal Plus el 19 de Septiembre de 1.990, la 4 el 7 de Noviembre de 2.005, la regional vasca Euskal televista el 1 de Enero de 1.983, la regional catalana Canal 33 el 27 de Abril de 1.989, la regional andaluza Canal Sur el 27 de Febrero de 1.989, la regional Canal Gallego el 25 de Julio de 1.985, la regional valenciana Canal 9 el 9 de Octubre de 1.989, la 
regional catalana TV 3 el 10 de Septiembre de 1.983, la regional vasca Euskal televista en castellano en el año 1.986, la regional madrileña Tele Madrid el 1 de Septiembre de 1.986, la televisión desaparecida Canal 10 el 13 de Noviembre de 1.986. El año 2.006 han aparecido la Cuatro y la Sexta que se fusionan en el año 2.009. Hay 217 canales y 400 emisoras locales en toda España, como Canal plus 2, Canal plus cine 1, Canal plus cine 2, Localia, Cinemanía, Cine estudio, Cine español, TCM, Calle 13, Fox, AXN, Paramount, Canal disney, Documanía, Taquilla, National Geographic, Canal 7, Canal 39, Telemadroño, Onda 6, Televisión canaria, etc.

La estética de la televisión es muy importante, como arte undécimo, junto con el vídeo, la radio, el disco, el cassette, el magnetofón y el D.V.D. independiéntemente de la técnica y de la ética, el arte icónico es decisivo, aparte de la tecnología y de la publicidad, la creatividad audiovisual es enorme, además de la aplicación de la ciencia y de la propaganda comercial, ideológica, económica, política, moral y religiosa. La imagen de la pequeña pantalla atrae a la mayoría de la gente, aunque haya una minoría que no sufra tal efecto, de ello se aprovechan los políticos y los negociantes. Mi amigo Miguel Angel Martín Proharán (Proharán, 1.985) nos habla de la información televisiva como: económica, técnica y artística. El pretexto, el paratexto y el hipertexto del esquema 2 de otro libro mío (Hernáiz, 1.999: 34 y 35).

La teoría de la pérdida de la memoria, formulada por Platón (Gambra, 1.965) y G.Bruno (Yates, 1.983), a los que he citado en el segundo capítulo de otra obra (Hernáiz, 2.007), nos remite a que, con el paso de la sociedad oral a la alfabeta, Moisés al escribir el Pentateuco o los cinco primeros libros de la Biblia (Biblia, 1.960), suprimió la función de los ancianos judíos que contaban sus historias a los jóvenes. Lo mismo pasó en otras civilizaciones, al redactarse sus libros sagrados, como los Vedas en la India, el Chilan Balam en la cultura maya, etc. Igual ocurrió, en el renacimiento, cuando J.Gutenberg inventa la imprenta, en el año 1.456, con la difusión popular de los libros, antes patrimonio de la élite social. Ahora, en la tercera 
fase de la historia de la comunicación, como escribí en el tercer capítulo de otro texto (Hernáiz, 2.007), en la sociedad digital, como explica J.B.Terceiro (Terceiro, 1.996), en la era de la información, como expone Manuel Castells (Castells, 2.000), en la tercera ola que propone A.H.Toffler (Toffler, 1.996), la pérdida de la memoria, por influencia de la televisión, puede ser mayor si cabe. El individuo del futuro, a diferencia del ser humano del pasado con una memoria total, sin llegar al absoluto divino, y del sujeto actual, con una memoria parcial, no recordará nada. Por si fuera poco, encima de la televisión Internet, la mayor base de datos de la historia de la humanidad.

La U.E.R. europea comenzó el 12 de Febrero de 1.950, agrupando a 87 cadenas televisivas, la U.A.R. o A.B.U. asiática en Julio de 1.964, asociando a 58 cadenas, la A.I.R. o I.A.A.B. americana en el año 1.946, agrupando a 22, siendo sustituida por la O.T.I., el 19 de Marzo de 1.971, asociando a 25, la A.S.B.U. árabe el 9 de Febrero de 1.969 agrupando a 17, totalizando la O.I.R.T. 187. La C.T.F. en francés sólo consiguió 6 y fracasó.

La película "Farenheit 451" (I) dirigida por F.Truffaut, basada en la novela de R.Bradbury, nos avisa del peligro de la conciencia mediática, es decir, la falta de conciencia desalienada, por culpa de los medios de comunicación de masas o mass media, donde se queman los libros y la televisión dirige la vida. A.Huxley (Huxley, 1.962) en su novela "Un mundo feliz" es el mejor análisis de la sociedad decadente que vivimos, la masificación alienada, en el sentido de G.W.F.Hegel (Hegel, 1.807) llevada al límite que ellos no llegaron ni siquiera a imaginar. "El show de Truman" (V) es otro filme dirigido por P.Weir, interpretado por J.Carrey, basado en la novela de A.Niccol, donde el público llora, ríe, ama con el protagonista de una serie televisiva interminable. La revista "Pronto", en su página 43, en la segunda semana de Diciembre de 1.999, sacó un reportaje de un programa de la televisión holandesa, espiando una casa de la ciudad de Almere. El programa “Gran hermano" de Tele 5, el del hotel de la misma cadena y el del autobús de Antena 3 siguieron idéntico 
camino. Holanda vuelve a ser pionera con el trasplante de órganos en directo televisivo.

M.Shulman (Sartori, 2.003: 63 y ss) llamó a la televisión: ojo universal, ojo hambriento, ojo malo, chicle para ambos ojos, vasto desierto y hábito de no elección consciente. R.Barthes (Barthes, 1.988) escribió: "La repugnancia a desvelar sus códigos, es una característica de la sociedad burguesa y de la cultura de masas". J.Baudrillard (Baudrillard, 1.984) decía que, la televisión, se confunde con la vida y, la vida, con la televisión. La atracción de la caja tonta o idiot box es muy superior al cine, a la radio, al vídeo, a la prensa, a la pintura, a la literatura, a la música y a todos los medios de comunicación de masas o mass media y elitistas, lo cual la convierte en el principio fundamental de la sociedad de consumo o del bienestar o postindustrial, a través de la publicidad comercial o espots propagandísticos o anuncios comerciales, lo que sale en televisión es lo que se vende.

También la propaganda política es básica, el político que no sale en la pequeña pantalla no gobierna. La magia del icono ha cerrado el ciclo de veinte mil años, volviendo a las cuevas paleolíticas, pintadas rupéstremente, con la única diferencia tecnológica, a los pelos de los animales ensangrentados les han sustituido los cables de alta definición, al barro los satélites. Pero la ética es la misma, el brujo dirigente de la tribu se ha convertido en el lider de la campaña electoral. Y, lo que nos interesa en este libro, la estética es igual, la belleza de las cuevas de Altamira tiene su correspondencia en los documentales o películas trasmitidas por televisión. La telebasura de los programas de cotilleo no.

El fenómeno phi de Münsterberg (Ornia, 1.991: 13 y ss) sobre la retentiva perceptiva, definida como un punto de luz en movimiento incesante, nos lleva al concepto de zapear o zapping, es decir, la cuestión del tiempo, la básica de la filosofía, por lo tanto, del arte. 
Ya plantee, en el cuarto capítulo de otro texto mío (Hernáiz, 1.999), como en el renacimiento, al recrear la perspectiva clásica, teníamos una tridimensionalidad en un momento dado, con un foco de luz. En el sexto capítulo de ese libro, al analizar el impresionismo y el barroco, veía como, la monofocalidad, se tornaba en bi o trifocalidad, además de intentar la cuatridimensionalidad plástica, uniendo el tiempo a las tres dimensiones espaciales: altura, anchura y longitud. Se quieren ver más imágenes por segundo. La conciencia mediática o la alienación que experimenta la sensibilidad humana a través de los medios de comunicación, está en función de ese consumo incesante de iconos, de esa necesidad obsesiva de ver imágenes diferentes.

El laberinto del poder, según Miguel Angel Rodríguez Bajón (Bajón, 1.998), donde las noticias televisivas sólo se dan para que quepan los anuncios publicitarios o espots, tiene su Minotauro en la manipulación de la pequeña pantalla. La libertad de las cadenas televisivas es falsa, puesto que se ponen de acuerdo para, aunque los espectadores zapeen, estén con los anuncios a la vez en todas las cadenas. La libertad, concepto filosófico desalienante, como explico a continuación, es manipulado por el acuerdo de las cadenas televisivas, por lo tanto, volvemos a la conciencia mediática, como modificación de la sensibilidad. De la misma manera, los políticos, sobre todo en las campañas electorales, bombardean a los teleespectadores, siendo imposible escapar, no hay cadena independiente del poder político y económico.

Ch.Revson (Mellers, 1.985) escribió: “en nuestra fábrica hacemos lápices, en nuestros anuncios vendemos esperanza". Se refiere a lápices de pintarse las mujeres y, la esperanza, no es la virtud teologal, sino el afán de ligue. J.K.Galbraith (Galbraith, 1.981) calculó que, si los anuncios de televisión desaparecieran, el producto nacional bruto se reduciría a la mitad. Afirmó W.Mellers (Mellers, 1.985) que, los espots publicitarios, arrastran con ardides y engaños a la compra de determinados bienes y recursos. Añadió que, el presidente Eisenhower de U.S.A., fué el primero que utilizó, 
hace medio siglo, la televisión en la campaña electoral. El guapo J.F.Kennedy venció al feo R.Nixon por el primer debate en la pequeña pantalla.

Narciso Ibáñez Serrador realizó una serie "Historias para no dormir" (VI), un capítulo dedicado a la influencia de la televisión, interpretada por su padre Narciso Ibáñez Menta. José Luis Sáenz de Heredia dirigió la película “Historias de la televisión" (VII), interpretada por Tony Lebranc, la hermosa Conchita Velasco y José Luis López Vázquez. Halashby realizó el filme “Bienvenido Mister Chance” (VIII), interpretado por P.Sellers, el cual ve la televisión hasta en el retrete. P.Hyans dirigió la película "Permanezca en sintonía" (IX). S.Lumet realizó el filme "Network, un mundo implacable" (X), interpretado por W.Holden, sobre las luchas políticas dentro de la estructura televisiva. R.Redford dirigió la película "Quickshow" (XI), sobre un concurso de televisión. J.L.Brooks realizó el filme "Al filo de la noticia" (XII). B.Levinson dirigió la película "Cortina de humo" (XIII), interpretada por R.De Niro, sobre la manipulación televisiva por parte del gobierno. R.Howard realizó el filme "Ed tv" (XIV), al estilo de “El show de Truman" (V).

G.Sartori (Sartori, 2.003: 76, 83, 87, 116, 151, 160 y 196) escribe que: “como piensa J.Baudrillard, la información, en lugar de transformar la masa en energía, produce más masa.... la Biblia, impresa por J.Gutenberg, entre los años 1.452 y 1.455, produjo doscientas copias.....la lógica establece las reglas de pensamiento correcto que son reglas de concatenación deductiva, no de concatenación causal......la televisión refleja los cambios que promueve e inspira a largo plazo......información no es conocimiento......el seudoacontecimiento es un hecho que acontece sólo porque hay una cámara que lo está rodando......E.Burke, en Bristol (Inglaterra), en el año 1.774, habló del cuarto poder......"El mundo feliz" de A.Huxley, escrito en el año 1.931 y, reelaborado, en el año 1.959......la televisión está creando una lumperinteligencia.....el primer grupo de referencia es la familia, el segundo la escuela, el tercero la pandilla y el cuarto los medios de comunicación.....la libertad 
defensiva se opone a la libertad positiva". Aunque la fecha de la imprenta es el año 1.456.

R.May (May, 1.959) diferencia cine y televisión, como dos lenguajes icónicos distintos, por las siguientes características: el filme es mediato, la televisión es inmediata, la película de la gran pantalla es expresiva, la de la pequeña es evidente, el cine es significativo y la caja tonta es elocuente, el filme está pensado para un público colectivo y la televisión para individuos. El teatro coincide con la televisión menos en el público. El vídeo y la televisión de pago coinciden con el teatro y la televisión, menos en la interrupción voluntaria.

S.Pollack dirigió la película "Tootsie" (XV), interpretada por D.Hoffman, haciendo de mujer para una serie televisiva. F.Fellini realizó el filme “Ginger y Fred” (XVI), sobre una imitación televisiva de los famosos bailarines. Chema Carbajosa dirigió la película "Zapping" (XVII) sobre la obsesión de zapear la televisión, buscando todos los canales. S.Frears realizó el filme "Héroe por accidente" (XVIII). Pilar Miró dirigió la película "Gary Cooper que estás en los cielos" (XIX), sobre la relación ideal de ella misma, directora de cine y de televisión española, con el famoso actor. M.Radford dirigió la película "1.984" (IV), interpretada por R.Burton, sobre la novela de G.Orwell (Orwell, 1.948), cambiando las dos últimas cifras de su publicación, nos presenta una sociedad comunista estalinista, pues él era troskysta y estuvo en la guerra Civil española, gobernada por la televisión, llamada el gran hermano. "Pleasantville" (XX), interpretada por W.H.Macy, sobre la manipulación televisiva, al estilo de "El show de Truman" (V). R.Rossellini (Ferro, 1.995), el director italiano neorrealista de cine, creyó que éste sería sustituido por la televisión. J.L.Godard (Godard, 1.980), el director francés de la nouvelle vague o nueva ola gala, comparó cine y televisión, con Caín y Abel, los hermanos bíblicos, hijos de Adán y Eva, asesino el primero del segundo, pues la pequeña pantalla mata a la gran pantalla, en el sentido de que le quita espectadores y, por ejemplo, hemos ido viendo desaparecer 
los cines de barrio. Alex de la Iglesia realizó el filme "Muertos de risa" (XXI), sobre una crítica humorística de la televisión. B.Fosse realizó el filme “Empieza el espectáculo" (XXII). C.Gabras dirigió “Mad city" (XXIII). M.Allegret realizó la película “Una rubia peligrosa” (XXIV). M.Forman dirigió el filme "El hombre de la Luna" (XXV), al estilo de "El show de Truman" (V), también interpretada por J.Carrey. E.Kazan realizó “Un rostro en la multitud” (XXVI) sobre el mismo tema, el poder de la televisión, cuando un individuo es capaz de vender un producto comercial, político o ético, sin calidad mercantil, social o moral, sólo contando con su simpatía personal.

S.Kubrick dirigió la película "2.001, una odisea del espacio" (XXVII), basada en la novela de A.C.Clak donde, a demás de la elipsis más famosa de la historia del cine, del monolito símbolo divino, del mono criminal como principio de la inteligencia, de la iluminación por debajo para evitar las sombras, de la primera utilización del grafismo cibernético y de la ciencia ficción espacial, está el tema del ordenador HAL (IBM son las siguientes letras del abecedario) que intenta matar a las personas, incumpliendo la ley de la robótica de I.Asimov (Asimov, 1.995), la cual dice que nunca un robot podrá atentar contra un ser humano. Igual ocurre con el filme realizado por R.Scott "Blade runner" (II), interpretado por H.Ford y basado en la novela de P.K.Dick. J.Carpenter realizó dos filmes "1.997, rescate en N.York" (XXVIII) y “2.013, rescate en Los Angeles” (XXIX) sobre la temática de las sociedades del futuro, sin utopías como expuse el 20 de Septiembre de 2.007, en el XIX congreso de sociología, en Caracas (Venezuela), alienadas por los medios de comunicación de masas o mass media, la conciencia mediática de lo políticamente correcto.

R.Kwietniowski dirigió la película "Amor y muerte en Long Island" (XXX). H.Frankin realizó el filme “Ojo público" (XXXI) sobre la prensa, el cuarto poder, según la frase intuitiva de E.Burke, aunque no sabía hace dos siglos lo que llegaría a ser, empezó pidiendo la libertad de expresión y ahora hace caer a gobiernos, como el 
caso de R.Nixon atacado por el periódico "Washington post" en la película "Todos los hombres del presidente" (XXXII) realizada por A.J.Pakula e interpretada por D.Hoffman y R.Redford, sobre el escrito de C.Berstein. B.Ray ha dirigido "El precio de la libertad" (XXXIII) también sobre la prensa. Sin olvidar "Ciudadano Kane" (XXXIV) dirigida e interpretada por G.O.Welles, sobre el poder de W.R.Hearts que provocó la guerra de U.S.A. contra España por Cuba, en el año 1.898. "Scoop" (XXXV) dirigida, escrita e interpretada por W.Allen sobre una aprendiz de periodista. D.Aronofsky realizó la película "Pi” (XXXVI) sobre la informática y sobre la televisión "Réquiem por un sueño" (XXXVII). Internet, en tanto y cuanto se ha instalado en nuestras vidas, aunque hace tan poco que todavía es minoritario, empieza a preocupar a los pensadores, no sólo filósofos sino creadores del séptimo arte o cine, del octavo o la fotografía y del noveno o el comic o tebeo, del décimo el cartel publicitario o affiche, del undécimo la televisión y del duodécimo la cibernética.

D.Cannon dirigió la película "Juez Dreed" (XXXVIII), interpretada por S.Stallone y M.V.Sydok, sobre una sociedad del futuro gobernada por la televisión. N.Ephron dirigió la película “Tienes un email” (XXXIX), interpretada por T.Hanks y M.Ryan sobre el tema informático. J.Herzfeld realizó el filme “Quince minutos” (XL) sobre el cuarto de hora de fama que, a todos, nos corresponde en televisión, según A.Warholl. E.Kazan dirigió “Un rostro en la multitud” (XLI), hace ya tiempo, cuando todavía no se veía el problema de la alienación. G.Clooney dirige “Buenas noches y buena suerte" (XLII) sobre la caza de brujas del senador Mc Karty y la respuesta de la cadena televisiva CBS.

Aparte de la televisión, aunque es el medio de comunicación de masas más influyente, existen otros mass media que también condicionan la libertad del ser humano, alienándole en el sentido de G.W.F.Hegel (Hegel, 1.807), como ya he dicho, impidiéndole desarrollar su sensibilidad hacia la cultura, el arte, la ciencia, la religión 
y la filosofía. La radio, en mucha menor medida, también contribuye al proceso de alienación, por eso se han hecho algunas películas, muchas menos que sobre la televisión. Al citar los filmes mato dos pájaros de un tiro, apoyo mi tesis con filmografía, igual que con bibliografía y específico la necesidad consumista del cine en la sociedad del bienestar, haciendo historia fílmica, sería el género comunicacional.

José Luis Sáenz de Heredia, el primo hermano de José Antonio Primo de Rivera y Heredia, el fundador de la falange española, dirigió la película "Historias de la radio" (XLIII). W.Allen realizó el filme “Días de radio" (XLIV). También la película "Sueños de seductor" (XLV), dirigida por H.Ross, donde condena al Infierno a todos los medios de comunicación. "Seduciendo a un extraño" (XLVI) dirigida por J.Fillet e interpretada por B.Willis saca el tema de los correos electrónicos. "Retrato de una obsesión" (XLVII) dirigida por S.Shainberg, sobre la vida de la fotógrafa D.Arbus e "Intimo y personal" (XLVIII) realizada por J.Avnet e interpretada por R.Redfort y la guapa M.Pfeifer sobre el tema televisivo. Naturálmente, hay buenos periodistas, sobre todo en la prensa, en la radio y en Internet, pero en televisión abundan menos. E.Carpentier (Castells, 2.001) escribe que la televisión globaliza, por ejemplo, en la retrasmisión de las olimpiadas deportivas. Dos verbigracias de la vida cotidiana nos indican el poder de la televisión: para dormir la siesta acompaña y, cuando se llega a casa, lo primer que se hace es encender la pequeña pantalla, antes de ir al retrete y a la cocina. Si un extraterrestre bajara a la Tierra creería que la televisión es Dios, por la adoración colectiva. N.A.Chonsky (Chonsky, 1.994) dice que, a las dictaduras fascista y comunista, les ha sustituido la manipulación democrática de la caja tonta y de otros medios de comunicación de masas o mass media.

La conciencia mediática no tiene la cultura de los libros ni la incultura analfabeta, posee la seudocultura de los mass media. La cultura de los medios de comunicación 
de masas no es, ni en el sentido de Sócrates (Montanelli, 1.963), ni en el de Lao Tsé (Ling, 1.968) ni en el de J.W.Goethe (Cahn, 1.970), la dialéctica con la naturaleza. Ya no existe la antítesis renacentista de la civilización y la naturaleza, ya no hay la oposición china de ciudad y campo, ya no es antagónica la urbe al agro, como en el romanticismo, ya no está en contra el burgo de la barbarie, como en el feudalismo medieval, ya no se enfrenta la polis al salvajismo, como en la Grecia clásica.

La síntesis dialéctica es la conciencia mediática, de la tesis de la naturaleza y de la antítesis de la cultura, haciendo turismo por la pequeña pantalla. La mezcla de ignorancia y sabiduría es la conciencia mediática, donde el individuo masa repite como un papagayo lo que dicen los medios de comunicación.

La unión de bondad y maldad es la alienación producida por los mass media, donde el sujeto no hace positívamente ni negativamente, sólo imita a los comportamientos que salen en la televisión. La conciencia mediática es la reconciliación de la historia con la persona, no el individuo sino el alma colectiva, en el sentido de G.W.F.Hegel (Hegel, 1.807), puesto que la sociedad de masas rebelada, como veía José Ortega y Gasset (Ortega, 1.987: 45), anula al ser humano en su inteligencia. La conciencia mediática es la de la técnica, como explicó M.Heidegger (Heidegger, 1.999), el alma colectiva de hoy, el volksgeist o espíritu universal. J.Lovelock (Mc Luhan, 1.960) habla de gaya o el conjunto de vida terrestre, como una unidad, la cual tiene su alma.

Un ejemplo de la conciencia mediática, sustituyendo a la religión, lo tenemos en las Navidades, la fiesta cristiana del 24 de Diciembre, ha sido anticipada comercialmente a Octubre, por medio de la televisión y otros medios de comunicación social, puesto que la actividad mercantil empieza dos meses antes, la venta de la lotería en Agosto. Como decía el cómico G.Marx, la televisión es muy culta, en cuanto alguien enciende el aparato, me voy a otro cuarto a leer. Como afirmaba el coreano N.S.Paik (Sartori, 2.003: 78), la televisión comunica, como el sexo. La importancia de la televisión 
aumentó con el invento del mando a distancia, ya no hay que moverse del sillón. Según la U.N.E.S.C.O. (organización de las naciones unidas para la cultura, la educación y la ciencia), en el año 1.992, había mil millones de receptores, un sexto del de la población, variando desde un 35\% europeos, 32\% asiáticos, 20\% norteamericanos, 8\% iberoamericanos y 5\% africanos. Existen unos trescientos canales emisores. Hay críticos que piensan que no influye tanto la televisión, simplemente que es más propia a las anécdotas. El tiempo se ajusta a la televisión, la hora de dormir y de comer.

La alienación televisiva, conocida como telebasura de la caja tonta o idiot box, es un concepto muy importante que he definir muy bien, para entender su relación con la pintura, el cine, la literatura e Internet. Los medios de comunicación individuales que son las bellas artes tradicionales: literatura, arquitectura, escultura, pintura y música, así como las artesanías, son relaciones personales del autor con el receptor del mensaje. Empezó con el teatro o sexto arte y con el cine o séptimo la masificación.

La alienación televisiva es la de los partidos de football o futbol, la de los programas de cotilleo o prensa del corazón y la de las telenovelas iberoamericanas como "Loco de pasión", “Rubí", "Frijolitos", "Plateados", "La tormenta", "Corazón partido", "Destilando amor", "Contra viento y marea", "La madrastra”, "Cuando tu vuelvas", "La dueña" o "Pasión de gavilanes". Lo que, en la filosofía hegeliana, llamamos alienación o conciencia mediática, según mi terminología, es la comunicación de masas o mass media, para E.Morin (Sartori, 2.003: 79), la cual reúne las diez siguientes características ontológicas: simpatía, happy end o final feliz, novelesca, idolatría de los famosos, violencia, erotismo, búsqueda de la felicidad, ansía de amor, culto al feminismo y adoración da la juventud. Es el concepto que relaciona a los otros. La alienación empezó a ser definida por G.W.F.Hegel (Hegel, 1.807), el cual al formular el primer pensamiento dialéctico, antes eran filosofías estáticas, excepto alguna intuición como la de Heráclito de Clío el Oscuro (Bermejo, 1.996) o la de Lao 
Tsé (Ling, 1.968), el creador del taoismo chino; con las tres leyes dialécticas que analizo a continuación, presupone el desdoblamiento de la conciencia, en el amo y en el esclavo metafóricamente, a lo cual llamo conciencia mediática, K.Marx (Marx, 1.873) denominó enajenación económica del obrero por la explotación social del capitalista y S.Freud (Maynard, 1.987) sicológica o represión del inconsciente sobre el consciente. Por lo tanto, es una superestructura ideológica, según el marxismo fruto de la infraestructura económica de los modos de producción, puesto que la conciencia está determinada por la existencia.

Frente a esa teoría, M.Weber (Weber, 1.977) propuso la contraria, es la superestructura ideológica la que crea la infraestructura económica, estudiando el principio del capitalismo, a consecuencia de la reforma protestante. El protestantismo vuelve al Antiguo testamento judío, mientras que el catolicismo se parece más al islamismo, en esta cuestión. H.M.Mc Luhan (Mc Luhan, 1.960) llamó extensión tecnológica de la conciencia a la que he denominado mediática. N.Hawthorner (Sartori, 2.003: 80) lo definió como un gigantesco nervio de inteligencia.

\section{Internet}

Pero no sólo la televisión, como dije en el tercer capítulo de mi último libro (Hernáiz, 2.007), también está Internet que es la globalidad planetaria, más que la televisión, lo que ocurre es que lleva poco tiempo, sólo veinte años. Por lo tanto, todavía no podemos calificarla de alienante, no tiene un gran poder sobres las masas. Sin embargo, como toda la cibernética no es Internet, el ordenador no es comunicación de masas, en tanto y cuanto es una máquina de escribir, pero si hay cinco aspectos de la informática que son comunicación: el correo electrónico o email, el chat, el foro de debate o sistemas de relaciones, el diseño gráfico y el videojuego. Pero no son universales, por lo tanto, sobre todo el videojuego está restringido a los jóvenes de la sociedad de consumo, ni los viejos de la cultura del bienestar ni los jóvenes del tercer 
Mundo participan.El software es el intratexto, como expliqué en el primer capítulo de otro libro mío (Hernáiz, 1.999: 34 y 35), el programa informático, el hardware es el paratexto, el ordenador y, la comunicación, el metatexto. Hay tres generaciones: la del ordenador, la unida al teléfono y la del móvíl.

Desde el invento de B.Pascal (1.623 - 1.662) de la máquina calculadora, de G.G.Leibniz (1.646 - 1.716), de C.Baggage y de la esposa G.Gordon de lord Byron, como creaciones prehistóricas de la informática, la historia de la cibernética comienza con V.Newmann, cuando crea el primer ordenador, en la década de 1.950, pesando varias toneladas; T.H.Maiman crea el rayo laser, en el año 1.916, N.S.Kapeny la fibra óptica, en el año 1.945, al mismo tiempo que N.Wiener perfecciona la computadora de H.Aiken, en el año 1.937, J.V.Atanasoff, en el año 1.939, J.Mauchly, en el año 1.951 y S.P.Jobs, en el año 1.972; y en el año 1.969, dos ingleses y dos norteamericanos, descubren Internet, aunque no es hasta el año 1.989, cuando empieza wordl wide web. P.Kunz en la universidad autónoma o libre de California, lo perfecciona el 12 de Diciembre de 1.991.

A.Einstein (1.879 - 1.955) estuvo a punto de llegar al invento, pero murió antes de conseguirlo. D.Eisenhower el presidente norteamericano y general victorioso de la segunda guerra mundial o civil europea, autorizó el programa ARPA en el año 1.957. Noruega y Gran Bretaña se unieron a ese programa militar en el año 1.973. J.B.Terceiro (Terceiro, 1.996) plantea que, a las dos dimensiones físicas clásicas: materia o hardware y energía, hay que añadir información o software. A las tres dimensiones espaciales de la materia: longitud, altura y anchura, se le añade la cuarta del tiempo estático y la quinta del dinámico o velocidad, la relación de tiempo y espacio, dilatamos la cuarta a la quinta, diferenciando lo visual de lo auditivo, el cine, siendo la sexta el movimiento que crea la energía, distinguiendo la séptima para la información, compartida con el alma colectiva de la literatura y la prensa, el intratexto, según mi terminología. 
El byt o binary digital es la unidad, el KB o kilo byt equivale a mil byts, el MB o mega byts a un millón de byts y el Giga a un billón americano o mil millones. IBM y Macintosch son las dos marcas principales. La capacidad humana de captar imágenes es de 16 byts por segundo, en el cine es de 24 y en televisión de 25. La cibernética, como la aviación, es un invento que ahorra mucho tiempo, cuando funciona, pero, a veces, se pierde en los aeropuertos e intentando entrar en Internet o llegar a lo que estás buscando. Es un lenguaje y lógica diferentes, a la que se adaptan mejor los jóvenes que los viejos, educados en su idioma y gramática, no ya sólo porque sea en inglés, cuando se procede de otro idioma, es por las abreviaturas. La lógica de Aristóteles (Bermejo, 1.996), renovada por la escolástica, no sirve para la informática que es simbólica y, el símbolo, significa media moneda, en latín, que los romanos se daban para reconocerse. A.Moles (Chonsky, 1.994) diferencia la información semántica o denotativa y estética o connotativa. Esta segunda acepción es la que venimos definiendo desde el principio de este artículo.

Dieciseis millones de usuarios españoles se conectan con el administrador de la red Telefónica, empresa que tiene filiales: Terra, Movistar y Lycos. De banda ancha existen seis millones de usuarios. Hay otros proveedores: Internet que es universal, Arpanet que es militar e Intranet que es privado. Existen varios servidores: Google, Hotmail o MSN o Microsoft, Yahoo, Yacom, Mixmail, Jazzfree o Jazztel, Wanadoo, Telecom o Movilcom, Excita, Altavista, Teleline, Ticali o Bonti,Guay, 3.000. Iespana o Prodigy, AOL o Latinmail y Compuservice. Estos tres últimos los primeros del año 1.993. Los cuatro grandes son: Microsot, Yahoo, AOL y Wanadoo, la mayor AOL al fundirse con Time y Warner el año 2.000. Yahoo la fundan dos jóvenes J.Yang y D.Fito, para la compañía Inktami. Microsoft la crea B.Gates, en el año 1.983, amasando la mayor fortuna del planeta. Google la crean S.Brin y L.Page, en el año 1.996, dos jovenes de la universidad UCLA de California. Excite, desde el año 1.995, compite con Wikipedia, Google, Yahoo y Lycos. 
Cuatrocientos millones de usuarios completan la red global, dos millones de correos electrónicos o e mails por segundo y cincuenta millones de páginas web. Se reparten: 42,6\% en U.S.A., 23,8\% en Europa occidental, 20,6\% en Asia, 4\% en Ibeoamérica, 4,7\% en Europa del Este, 3,7\% en Ocaña y 0,6\% en Africa. El t ercer M undo que ya estudi é ( Hernáiz, 1.983 ) , seguirá siendo pobre, cada vez más, puesto que el continente negro tiene menos ordenadores que la isla de Manhattan, no ya la ciudad de N.York, según M anuel Castells ( Castells, 2.001 ). La ilusión de la amistad lejana, a través de Internet, es una de las características de la globalidad, como con el teléfono móvil, los jóvenes mayoritariamente se relacionan o chatean, se citan, se mandan mensajes, pueden llegar a tener una experiencia sexual y a otra cosa que la vida es corta.

Internet es la sociedad de la información, más que la televisión y que los otros medios de comunicación de masas o mass media, es la mejor tela de araña planetaria, la noosfera de J.M.P. Teilhard de Chardin ( Teilhard, 1.966 ), el volksgeist o espíritu popular o universal de G.W.F. Hegel ( Hegel, 1.807 ), gaya de J.Lovelock, el mundo unitario de K.Jaspers ( Jaspers, 1.968 ) y la aldea global de H.M. Mc Luhan ( Mc Luhan, 1.960 ). La diferencia entre la sociedad de la información y la globalización terráquea, conceptuálmente, en la práctica es Internet y la televisión respectívamente; la distancia filosófica son las teorías expuestas: la conciencia mediática y la sensibilidad no alienada. El ser humano ha recibido siempre, a lo largo de toda la historia de la humanidad, por la percepción sensorial o sensibilidad externa, unas treinta mil sensaciones por segundo, ahora llegan a la persona, a través de los medios de comunicación muchas más, el individuo tiene una superinformación. Como siempre, la sensibilidad externa producía la interna, la que nos interesa en el arte, en la religión, en la filosofía y en la ciencia, en el repliegue del espíritu hegeliano, por eso la sensibilidad es más real. Un alma insensible es menos real, en el sentido hegeliano, pues el cuerpo material está en la realidad. Una inteligencia que ha desarrollado la sensibilidad interna, pues la externa kantiana (Kant, 1.984) o percepción es una parte de ella, como la intuición o la imaginación, la reflexión o el 
pensamiento, el sentimiento o la emoción y la decisión o voluntad; si la ha desarrollado evolutivamente, por contradicción con las circunstancias, como expli qué ( Hernáiz, 1.988 ), llega a la captación estética y ética.

El año 1.945 se crea ENIAC (electronic numerical integrator analyser computer) en Pensylvania (U.S.A.), por J.Presper y J.Mauchly, de treinta toneladas de peso, de treinta metros por tres y por uno, largo, ancho y alto respectívamente, con seis mil cables. El año 1.949 se origina EDSAC (electronic delay storage automatic calculator) en Cambridge (Inglaterra), por M.Wilkes. IAS en Princeton (Norteamérica) por J.Bigelow. Mark en Harvard (U.S.A.) por Haken, en el año 1.937, son los cuatro ordenadores de la primera generación. J.V.Atanasoff, en el año 1.939, crea las palabras informática y cibernética.

La segunda es, a partir del año 1.958, con la invención de los transistores.

El año 1.950 había 15 ordenadores, el año 1.955, doscientos, el año 1.960, 5.272, el año 19 70, 200.000, el año 1.980, 350.000, el año 1.981, 694.000, el año 1.982, 926.000, el año 1.983, 1.500.000, el año 1.984, 2.400.000, el año 1.985, 3.300.000, el año 1.990, 98.000.000, el año 1.995, 222.000.000, el año 2.000, 579.000.000, el año 2.001, 625.000.000. alcanzando el número de teléfonos 600.000.000 y el de televisores 680.000.000 al acabar el milenio. El 75\% de los ordenadores están en Europa y Norteamérica, teniendo en cuenta que, del 25\% restante, la mayor parte están en Japón, Australia, Israel e Iberoamérica, para Africa y Asia no queda mucho.

Comparemos las cifras históricas de cualquier medio de comunicación individual con éstas, estamos hablando de un invento de hace medio siglo que ya, desde el estudio de Manuel Castells (Castells, 2.001 ), han pasado ocho años, por lo tanto, estaremos en el billón americano o mil millones de ordenadores. La tercera 
generación comenzó, en el año 1.970, con los miniordenadores. La cuarta, en el año 1.980, con los ordenadores personales.

La quinta, en el año 1.990, con los ordenadores portátiles. La sexta o multimedia, combina la cibernética, la televisión, el vídeo y el teléfono de tercera generación, la primera es el eléctrico y, la segunda, el móvil o inalámbrico. N.Wiener (1.894 - 1.964) , en el año 1.948 , con su libro sobre cibernética, como C.E.Shannon, en el año 1.949, lanza la teoría matemática, llamando codificador al emisor de la teoría de la información: emisor, trasmisor y receptor. Al medio de trasmisión le denomina señal y, al receptor, decodificador. A.Moles (Chonsky, 1.994 ) llama noticia al trasmisor. Se calcula que, cada año y medio, se duplica la información almacenada cibernéticamente. En el futuro habrá un basurero informá tico, como ahora el mar lleno de los desperdicios de siglos y de barcos hundidos, la atmósfera plena de información, la noosfera a tope de comunicación, el aire contaminado de software, aparte de la Tierra con el hardware y los restos materiales de coches, aviones y otras máquinas.

J.Bardeen, W.Brattain y W.Shockley premio Nobel, descubrieron la utilización del germanio, en el año 1.947, sustituido por el silicio, en el año 1.954, por G.Teal, en el año 1.974, el chip. En Los Angeles, en el año 1.975, se pone la primera tienda de venta de ordenadores, Apple en el año 1.980, Macintosch en el año 1.984, compitieron con IBM que, en el año 1.961, vendía el PC u ordenador personal y, el microprocesador, en el año 1.981, descubierto por Noyce, en el año 1.971, perfeccionando el circuito integrado de G.W.A.Dunner, en el año 1.952. Desde el punto de vista de la teoría de la división del trabajo, en la sociedad tradicional o agrícola no había más que la que indicaba el sexo o la edad, en la sociedad industrial empezó y, en la postindustrial y en la superindustrial o de la información, se han calculado veinte mil oficios distintos, por el departamento de trabajo de U.S.A. Véase el esquema 2. 
El ratón, continuando con los inventos cibernéticos, lo creó D.Engelbart, el año 1.945, en S.Francisco (Estados Unidos). Arpanet nació el año 1.962, en U.S.A., en el ámbito militar, dirigida por J.Licklider, el diseño fué de Bolt, Beronik y V.Newmann, paralelo a TCP/IP. La interfaz gráfica de Macintosch se originó el año 1.968, por B.Atkinson. El correo electrónico lo inventó R.Tolimson, el año 1.970, es el 85\% de Internet. Módem se creó el año 1.977, en Chicago, por W.Christensen y R.Suess. Umex nació el año 1.979, en Carolina del Norte, por Truscott, Ellis, Bellavin y Rockwell. Bitnet se fundó en el año 1.981, por IBM. Milnet se creó el año 1.983, por los militares yankees. World wide web se originó el año 1.98 9, por T. B.Lee y R.Calliau , como he dicho anteriórmente . Limux se creó el año 1.991, en el MIT, por L.Torvalds. Netscape se creó el año 1.985.

M anuel Castells ( Castells, 2.001 ) albaceteño profesor de la universidad de Barcelona, explica: “La cultura Internet tiene cuatro estratos: la tecnocrática, la hacker, la comunicativa y la emprendedora.....los protocolos TCP/IP de Arpanet y del sistema Unix, Uucp de Usenet News, Módem de PC, del programa www, del navegador Netscape y del servidor Apache. Otro sistema es GNU/Limux....Los lenguajes son: Java y Jini..... El año 1.980 existían tres culturas informáticas: Arpanet de máquinas PDP - 10 y programa LISP, Unix con lenguaje C y PC de microordenadores, y lenguaje Basic". Microsoft, Motorola, Nokia, Intel, Cisco, Microsystems, Dell, Oracle, EMC, AOL, EBay, Amazon, H.Packard y Ericcson son las empresas multinacionales de informática. El índice Nadasq de la bolsa electrónica compite con el tradicional. Se calculan 550.000.000 de documentos cibernéticos, con un volumen de 1.500.000.000 de G igas.

La pregunta racional, pues irracionales pueden ser infinitas, es por qué escribo tantos datos informáticos. La idea es la siguiente: la historia de la comunicación, plantea la estética, desde las cuevas prehistóricas, como la de Altamira, la capilla sixtina del arte paleolítico, descubierta por Marcelino Sanz de Sautuola y Pedrezuela, en Santander 
(España); hasta esa red cibernética de medio billón americano de documentos, creados en medio siglo, lo cual indica que, en la próxima centuria será una cantidad billonaria europea, es decir, millón de millones.

Esa aldea global de H.M. Mc Luhan ( Mc Luhan, 1.960 ), de A.H.Toffler ( Toffler, 1.996 ), de J.B.Terceiro ( Terceiro, 1.996 ), de Manuel Castells ( Castells, 2.001 ) y de tantos otros pensadores que nos hablan de la realidad actual, como J.Lovelock, volviendo a los conceptos acuñados por J.M.P. Teilhard de Chardin ( Teilhard, 1.966 ), A.J. Toynbee ( Toynbee, 1.970 ), O.Spengler ( Spengler, 1.998 ), K.Jaspers ( Jaspers, 1.968 ) y de muchos otros historiadores que reflexionaron sobre la marcha de la humanidad, en el más puro sentido hegeliano. El 20 de Mayo de 2.009, en el Instituto universitario teniente general Manuel Gutiérrez Mellado de Madrid, dije que, el espíritu absoluto hegeliano, es la globalización.

Las tres dimensiones humanas: estética, ética y técnica se traslucen en este hecho: qué forma se le da, para qué se hace y cómo se crea. El arte, la religión y 1 a ciencia confluyen, tal como ver é en otro próximo libro sobre ética, pero dejemos ese tema y volvamos al de Internet, como creador de la conciencia mediática, al lado de la televisión y de los otros medios de comunicación de masas o mass media.

Se habla de la inteligencia artificial y de sus tres fases: las décadas 1.940, 1.950 y 1.960 ingénuamente, las décadas de 1.970 y 1.980 renunciando, las décadas 1.990 y 2.000 volviendo a querer crear la cyberbiología o relación de la informática con la biología, buscando el ordenador no sólo con inteligencia racional y perceptiva sino emocional e intuitiva. S.Kubrick dirigió “2.001, una odisea del espacio” (XXVII), una película con el ordenador Hal que veía y oía, además de tener lógica. Hal son las letras anteriores a IBM, la fábrica de ordenadores, en la novela de A.C.Clak, independientemente de que en Júpiter no hay más que gases. S.Spielberg ha hecho 
un filme sobre el tema del robot con sentimientos totalmente humanos (XLVIII). Robot es una palabra checa que significa humanoide.

B.Levinson dirigió la película "Acoso" (XLIX), interpretada por M.Douglas, la guapa D.Moore y D.Sutherland, sobre el tema tecnológico, aparte del sexual, el cibernético muy avanzado. I.Winklen realizó “Red” (L) interpretada por la bella S.Bullock.

Internet está considerado por Manuel Castells ( Castells, 2.001), una relación humana de tercera categoría, siendo las de primera los grupos sociológicos básicos: familia, amigos y colegio; los de segunda: trabajo, asociaciones políticas, deportivas, culturales y religiosas. Es una relación que pide menos esfuerzo físico y emocional, más mental, no hace falta levantarse de la silla y no hay que, como cuando se escribe una carta tradicionalmente, proponérselo. Un nuevo idioma ha nacido en Internet: protocolo, cookie, web, portal, puerto, chip, infografía, cibernética, disco, ordenador, email o correo electrónico, foro, ratón, chat, e mail, administrador, proveedor, usuario, diseño, red social, servidor, computadora, dominio o domain, wiki o colecciones de documentos, hoax o trampas, blog o diario de bitácora, hackers o informáticos, crackers o hackers delincuentes, mud o multiusers domains, sofware, hardware y navegador. Cookie es un marcador digital que la página web coloca automáticamente en el disco duro del ordenador. Sofware es la programación, distinta de la información, hardware es la máquina. Las demás palabras son usuales, pero en otros contextos. Chat es intercambio de información.

La teoría de la información se desarrolla, sobre los estudios de C.E.Shannon ( Terceiro, 1.996 ), en el año 1.916, tras la S egunda guerra mundial o civil europea, empeza n do como una cuestión militar, donde el esquema: emisor, trasmisor y receptor se complica si, el número de emisores aumenta, el de trasmisores también y, el de receptores, asimismo. Ya la hemos explicado en el noveno capítulo y último apartado. Por su parte, D.Bell ( Castells, 2.001 ) estudia los sectores sociales: el 
primario o agrícola con el sesenta por ciento de la población en los países subdesarrollados industrialmente, el secundario o industrial con el veinte y, el terciario o de servicios, con el otro veinte. En las naciones desarrolladas, el primario tiene el $10 \%$, el secundario otro $10 \%$ y, el terciario, más del $80 \%$, siendo estas personas las que consumen mucha más información.

Manuel Castells (Castells, 2.001) cree que hay tres posiciones en la información: las personas desinformadas, informadas y superinformadas. Las primeras repiten lo que dice la televisión, las segundas amplían sus fuentes de información a la prensa, la radio, el cine, los discos y los libros. Los individuos superinformados añaden Internet. Hay todas las combinaciones posibles, como desinformadas que repiten lo que dice la radio, informadas sólo por Internet y superinformadas por todo. Estamos en la tercera revolución industrial, la primera, la capitalista, la del vapor, la inglesa del siglo XVIII, extendiéndose a Francia, Alemania y U.S.A. en el siglo XIX, Europa occidental, Canadá

y Japón en la centuria XX, Rusia, Sudáfrica, Israel, Australia, Corea del Sur, Singapur, Formosa, China, Europa oriental e Iberoamérica en el siglo XXI, el Islam, India y Africa no llegarán hasta la centuria XXII, si llegan . La época de lo políticamente correcto es la de la alienación de la conciencia mediática de los medios de comunicación social o mass media o la rebelión de las masas de José Ortega y Gasset ( Ortega, 1.930 ) y la escuela del resentimiento de H.Bloom ( Bloom, 1.995, prólogo ). La segunda revolución es la de consumo o del bienestar o neocapitalista, en la que está Norteamérica, Europa del Oeste y Japón. La tercera es la de la información o postcapitalista que está empezando en esos tres bloques citados, los demás están en la segunda o primera o no han llegado. D.Bell (Castells, 2.001 ) habla de la sociedad postindustrial, como R.Darendorf ( Lucas, 2.002 ) de la postcapitalista y A.H.Toffler ( Toffler, 1.996 ) de la superindustrial, véase 1 os esquema s 1 y 2 adjunto s . 
Esquema 1 de las sociedades industriales :

Preindustrial Industrial Postindustrial Superindustrial

1

tradicional

estancada

aldeana

ampliada

machismo

dictadura

XL a.d.C. progresista

consumo

creciente

estancada

ciudadana

suburbana

3

información

población

informal

nuclear

feminismo

neohistoricista tecnocrática

ideología

política pensamiento

urbanización

familia

revolución

La explicación es fácil: la sociedad preindustrial, tradicional o agrícola, tenía el crecimiento de la población estancado, la urbanización era de tipo de aldea o pueblo o pequeña ciudad, la familia era ampliada a los padres, hijos, abuelos, tíos, primos y criados, la ideología sexual era machista y, la política, dictatorial, así fué durante más de cincuenta siglos. La sociedad industrial o de la primera revolución, la cual coincide con la inglesa del año 1.688, con el precedente del año 1.640 y con la francesa del año 1.789, continuada en los años 1.830, 1.848 y 1.870, en toda Europa, pues cuando París se acatarraba, se decía, el Viejo continente estornudaba; sigue teniendo vigencia el sentimiento tradicional, pero empieza el progresista con el conde C.R.H. 
Saint Simon (Saint Simon, 1.825) , como estudi é en mi tesis doctoral ( Hernáiz, 1.983 ); tiene la sociedad un incremento demográfico, la gente se va a vivir a las urbes, la familia es nuclear de solo los padres y los hijos, el feminismo es la ideología sexual, las primeras feministas fueron las saintsimonianas $y$, la democracia liberal, la política, cuyas ideas se desarrollan en Inglaterra y Francia en los siglos XVII y XVIII. Ya expli qué el precedente griego clásico, pero ahora no interesa. La sociedad postindustrial o de la segunda revolución o de consumo o del bienestar, coinciden las revoluciones rusa, china, etiope, cubana e iraní en los países tercermundistas, se estanca el incremento de la población, vive en los suburbios de las macrópolis, la familia es informal sin matrimonio religioso o monoparental, siguen las ideologías feminista y democrática, empezando la neohistoricista o revisión homosexual de la historia y la marxista ( Marx, 1.873 ). H.Bloom ( Bloom, 1.995: prólogo ) llama escuela del resentimiento a: semiólogos, estructuralistas, feministas radicales , neohistoricistas y marxistas ortodoxos . Naturálmente nos referimos a semiólogos fanáticos, estructuralistas exagerados, feministas lesbianas, gays radicales ideológicamente y marxistas estalinistas. El siglo XX es su escenario, coincidiendo con el Mayo de 1.968 en Francia y los precedentes de la caida del comunismo, en el año 1.989. M.Foucault el homosexual neohistoricista que revisa la historia del tercer sexo perseguido, lider del Mayo de 1.968 en París (Francia) y, diez años después, a favor de la revolución iraní que derrocó al Sha de Persia y proclamó la república islámica integrista de Jomeini.

La sociedad superindustrial es la de la tercera revolución, la de la información o de Internet, también la espacial, a partir del año 1.969, con la llegada a la Luna, pero es la centuria XXI, la de la conciencia mediática que no sabemos como va a afectar a las demás variables. L.Manovich (Castells, 2.001) ha creado el concepto interfaz para conectar el cine y la informática, como "Blade runner" (II) de R.Scott e interpretada por H.Ford, con Macintosh del año 1.984. La interfaz de la pintura y la cibernética está el formato horizontal que es el paisaje y el vertical el retrato. 
Esquema 2 de las ideologías:

Herencia - medio ambiente

clasismo - inferior - dominio - movimiento obrero - progresismo

racismo

“

11

negro

machismo

" "

" feminista “

progresismo - movimiento gay - genes - vicio - tradicionalismo

“

droga

“

juego

“

alcohol

"

tabaco

La explicación es sencilla, en la ciencia se discute si la causa es la herencia genética o el medio ambiente, de las clases sociales, para la derecha política es natural mientras que para el movimiento obrero es una situación de dominio injusto que el progresismo de la izquierda combate. La raza blanca superior a las otras es natural para los conservadores y no para los liberales. La superioridad masculina igual, causada por la naturaleza y no por la sociedad. Pero el progresismo cambia, con respecto al movimiento gay, defendiendo que es genética la causa de la homosexualidad y no adquirida, igual que la adicción a la droga, al alcohol y al 
juego, mientras que para el tradicionalismo son vicios, en el tabaco coinciden ambas posturas. Estos temas son los principales de los medios de comunicación de masas, por lo tanto, los creadores de la conciencia mediática.

El concepto filosófico de alienación es fundamental para entender la conciencia mediática de los medios de comunicación de masas o mass media, por lo tanto, analicemos a G.W.F.Hegel, tal como expuse en el XX Congreso de sociología en Santiago de Chile, el 20 de Septiembre de 2.008; teniendo en cuenta que no es la derecha hegeliana de F.W.Nietzsche y de A.Schopenhauer ni la izquierda de K.Marx y de su maestro L.Feuerbach discípulo directo de Hegel. El concepto del superhombre, plasmado políticamente en el führer A.Hitler, en el duce B.Mussolini y en el caudillo Francisco Franco Bahamonde, nada tiene que ver con la sensibilidad humana, al igual que la lucha de clases sociales que lleva a la dictadura del proletariado con V.I.Lenin, M.T.Tung, Fidel Castro y otros dirigentes comunistas.

\section{G.W.F. Hegel}

Guillermo Wilhelm Federico Hegel (27 - 8 - 1.770, 14 - 11 - 1.831) nace en Sttugart (Würtemberg), ciudad alemana que conserva todavía su casa, en medio del barrio de la prostitución; estudió en el seminario protestante de Tübinger Sift, con el poeta F.Hölderlin y el filósofo F.W.J.Schelling, admiradores los tres estudiantes de la revolución francesa; se casó en Nuremberg, con M.Tucher; siendo profesor de las universidades de Heidelberg, Jena y Berlín, la capital germana donde murió. Escribió catorce libros, relacionados en la bibliografía (Hegel, 1.829), donde analiza la historia de la humanidad en las "Lecciones de la filosofía de la historia", la ciencia en la "Filosofía de la naturaleza", la dialéctica en la "Ciencia de lógica", la religión en la "Filosofía de la religión", el arte en la "Estética", la ética, la moral y el derecho en la "Filosofía del derecho", la sicología, la antropología y la fenomenología que es la ciencia de los sentimientos en la "Fenomenología del espíritu", según W.Kaufmann 
(Kaufman, 1.968) uno de sus críticos. Podemos apreciar como, la dialéctica o aupheben de la tesis, antítesis y síntesis, triadas que forman, no sólo el pensamiento hegeliano, sino la forma de los capítulos, apartados y párrafos, tal como estudiamos (Hernáiz, 1.999); se configura sintéticamente su filosofía: tesis la lógica, antítesis la filosofía de la naturaleza y síntesis la filosofía del espíritu; la cual en la tesis es la filosofía del espíritu subjetivo, la antítesis la filosofía del espíritu objetivo y la síntesis la filosofía del espíritu absoluto; es el alma colectiva o volksgeist o espíritu popular, es lo universal, frente a lo individual de la persona y a lo particular de la raza, la clase económica, el sexo, la nación, la profesión laboral y el estatus social. La parousia del Juicio final, convierte a la historia de la humanidad en teodicea, escribió Hegel y también, el problema de la historia es la historia del problema.

Los doscientos once países y miles de regiones de la Tierra son lo particular, sólo quince centurias doradas, en siete imperios históricos, alcanzaron la universalidad, pues aunque hubo más imperios, no basta lo militar sino va unido a lo cultural, por ejemplo, los mongoles, los aztecas o los hititas. Los chinos, los egipcios, los judíos, los hindúes y los incas no salieron de sus fronteras, según O.Spengler (Spengler, 1.934), K.Jaspers (Jaspers, 1.968) y A.J.Toynbee (Toynbee, 1.970). La morfología de la cultura cree en la ley hegeliana del crecimiento, madurez y decadencia de las civilizaciones. J.M.P.Teilhard de Chardin (Teilhard, 1.968) y H.M.Mc Luhan (Mc Luhan, 1.960) creen, como Jaspers, en la cultura unitaria, llamándola respectívamente noosfera y aldea global.

Las siete universalidades son: el imperio romano, el persa-macedónico, el español, el francés, el alemán-austriaco, el soviético y el inglés-yankee. Los quince siglos de oro: judío del $\mathrm{X}$ a.d.C., ateniense del V a.d.C., persa de la misma fecha, chino igual, hindú lo mismo, romano del I d.d.C. y del XV, galo del X y del XIX, hispano del XIII y del XVI, germano-austriaco del XVIII, británico del XIX, ruso del XX y norteamericano del XX. Occidente, ha sido hecho por siete ciudades: Madrid, París, Londres, Berlín, 
Viena, Roma y Atenas. Se han incorporado Moscú o tercera Roma, N.York, Pekín y Tokio. Estambul o Constantinopla o Bizancio o segunda Roma, Damasco, El Cairo, La Meca, Persépolis, Jerusalén y Benarés son Oriente. Florencia es continuación de Roma, Toledo de Madrid y Occitania de París. El corsi y ricorsi de la historia que decía J.B.Vico (Vico, 1.981), es decir, el ir y volver, o sea, la repetición. No es que Hegel dijera exáctamente estas palabras, era su idea de la historia de la humanidad, la implicación de la fenomenología en la terminología. Siendo la filosofía del espíritu subjetivo subdividida, a su vez, la tesis es la sicología, la antítesis es la antropología y la síntesis es la fenomenología; mientras que, en la filosofía del espíritu objetivo, la tesis es el derecho, la antítesis es la moral o moralitat y la síntesis es la ética o eticidad; por fin, la tesis de la filosofía del espíritu absoluto es la historia, la antítesis es el arte y la síntesis es la religión. Criticándole el historicismo K.R.Popper (Popper, 1.955) y H.Marcuse (Marcuse, 1.967). Complicándolo más, las triadas dialécticas hegelianas son casi infinitas, esquemáticamente sería: primera tesis Dios o la idea, primera antítesis la naturaleza (aquí es donde K.Marx (Marx, 1.873) realiza la famosa inversión, diciendo que primero es la naturaleza y segundo la idea) y primera síntesis el ser humano. En la cita de Guillermo Cabrera Infante (Cabrera, 1.971): La naturaleza propone, Dios dispone y el ser humano postpone; podemos seguir el razonamiento de la primera triada.

La persona, en tanto y cuanto es alma, se convierte en tesis de la segunda triada dialéctica hegeliana cuya antítesis es el cuerpo y la síntesis el espíritu subjetivo. La tercera triada dialéctica hegeliana tiene como tesis el espíritu subjetivo o autorreflexión, como antítesis el espíritu objetivo o individuo que reflexiona y como síntesis el espíritu absoluto o volksgeist. Recordemos que, acabamos de explicar, el espíritu absoluto es la historia de la humanidad, el arte y la religión, ésta sería la cuarta triada dialéctica hegeliana. La historia, a partir de Hegel, es un conjunto de procesos sociales que convergen, siendo unos sometidos y otros dominantes, alternándose los dominados. El individuo es el ser humano y, la autorreflexión, es la 
reflexión o pensamiento que se piensa a si mismo. La quinta triada dialéctica hegeliana, como hemos expuesto, es la del espíritu subjetivo: sicología, antropología y fenomemología.

La sexta triada dialéctica hegeliana, también la hemos señalado, es la del espíritu objetivo: derecho, moral y ética. La conciencia desdoblada, la dialéctica del amo y del esclavo, no en un sentido social, sino sicológico, la acepción de la palabra; aunque luego el marxismo (Marx, 1.873), en el relativismo nocturno, creerá que todos los gatos son pardos, según la expresión hegeliana (Hegel, 1.829); es la alienación espiritual de la parte de la conciencia sometida. El volksgeist o espíritu popular o alma colectiva religiosa es la tesis de la séptima triada dialéctica hegeliana, cuya antítesis es la filosofía y síntesis el arte. El volksgeist es la patria, cuando no se cree en el alma colectiva no se es nacionalista, el internacionalista cree en la clase social y no en el espíritu popular, los obreros de los distintos países tienen más en común que con la burguesía paisana. Frente a los internacionalistas los paletos que no ven más allá de la torre del campanario de la iglesia de su pueblo, como siempre, en el término medio está la virtud, tal como expuso Aristóteles (Gambra, 1.965), nacionalista y ecumenista, defender lo nuestro positivo, no lo negativo, para querer también lo positivo ajeno.

La filosofía, asimismo lo he dicho, es: lógica, filosofía de la naturaleza y filosofía del espíritu, siendo la octava triada dialéctica hegeliana. La novena es el arte antiguo como tesis, el griego como antítesis y el cristiano como síntesis. El arte es la espiritualización de la sensibilidad humana, escribe Hegel y también, la vocación del arte es la libertad humana. La décima es la estética simbólica como tesis, la clásica como antítesis y la romántica alemana como síntesis, recordemos que era la época contemporánea de Hegel, como escribe T.W.Adorno (Adorno, 1.969). La undécima es la religión natural como tesis, la individual como antítesis y la absoluta como síntesis. La duodécima es la sicología como tesis, la sociología como antítesis y la 
antropología como síntesis; por supuesto la terminología moderna de sociología, la cual nacía con el positivismo, no la utiliza Hegel. La décimo tercera triada dialéctica tiene a la familia como tesis ética, a la sociedad como antítesis y al estado como síntesis. La décimo cuarta tiene como tesis familiar al yo, como antítesis al tú y comosíntesis al él. Véase el esquema 3 adjunto.

Esquema 3 de G.W.F.HEGEL:

Dios

Naturaleza

persona - alma

cuerpo

espíritu - subjetivo

objetivo

absoluto - historia

arte

religión

espíritu subjetivo - sicología

antropología 


\section{fenomenología}

espíritu objetivo - derecho

moral

ética

espíritu absoluto - alma colectiva

filosofía

estética

arte - antiguo

clásico

cristiano

religión - natural

individual

absoluta

filosofía - lógica

filosofía de la naturaleza 
filosofía del espíritu

estética - simbólica

clásica

romántica

alma colectiva - sicología

sociología

antropología

sicología - yo

tú

él

sociología - familia

sociedad

estado

estado - libertad natural 
libertad general

libertad universal

La décimo quinta y última triada dialéctica hegeliana tiene, como tesis estatal, la libertad natural, como antítesis la libertad general o de arbitrio y como síntesis la libertad universal; la cual es la libertad de conciencia religiosa kantiana o fenomenológica, mientras que la natural es la libertad marxista o económica o de fondo y la general es la générale roussoniana (Rousseau, 1.981) o de tous: de información o de prensa o de televisión o de radio o de comunicación o de palabra, sindical o de huelga, de circulación o de viajar, política o de manifestación, formal o de enseñanza o de educación, social o de asociación o de partidos políticos o de elecciones, aunque el suizo no las definiera así. J.J.Rousseau (Sabine, 1.974) postulaba la educación natural de los niños, pero a sus hijos los metió en un horfanato. K.Marx (Sabine, 1.974) predicaba la igualdad de los proletarios con los capitalistas, pero él le hizo un hijo a su criada, aparte de tener tres hijas con su esposa. C.L.S.Montesquieu (Sabine, 1.974) que era masón, dividió los poderes en ejecutivo o gubernamental, legislativo y judicial, como garantía de la libertad, pero E.Burke (Sabine, 1.974) habló del cuarto poder de la prensa, en Bristol (Inglaterra), en el año 1.774, hoy habría que decir de la televisión, aparte del quinto poder moderador del jefe del estado.

La libertad universal hegeliana (Hegel, 1.829) o de conciencia kantiana (Kant, 1.984) se sujeta a una escala de valores ética, mientras que la natural hegeliana, según A.Plebe (Plebe, 1.976) o económica marxista (Marx, 1.873) está reglamentada por el instinto y, por último, la general hegeliana o roussoniana (Rousseau, 1.981) no tiene normas morales y físicas, deontológicas y geográficas, religiosas y biológicas, es decir, sólo sociales. R.Aron (Aron, 1.991) distinguió las tres libertades: formal, de fondo y verdadera, es decir, liberal, socialista y religiosa. La verdad nos hace libres, según la Biblia (Biblia, 1.960), pues la mentira esclaviza, más que la tiranía y el 
trabajo. La libertad en Platón (Gambra, 1.965) o Aristocles de Atenas y Aristóteles (Gambra, 1.965) el Estagirita o príncipe de los filósofos, era la libertad de unos pocos ciudadanos: hombres, amos y griegos, no las mujeres de los eupátridas, los esclavos o ilotas y los extranjeros o metecos; el derecho de gentes y la ley natural; la libertad kantiana y hegeliana es extensiva a mujeres; esclavos y bárbaros, siervos y extranjeros, en la terminología posterior, ahora sería trabajadores y emigrantes, el derecho civil de J.Bodino (Sabine, 1.974), añadido a los otros dos; en este periodo histórico que vivimos se hace necesario, en la nueva edad Media, que explicamos (Hernáiz, 2.004); como hicieron S.Agustín de Hipona (Uscatescu, 1.983: 15) y Santo Tomás de Aquino (Santo Tomás, 1.265) el Buey mudo o Doctor seráfico, moderar la libertad, poner vallas al campo, controlar a los que confunden el todo con la parte y, la causa, con el efecto, principios de la escolástica, como ahora veremos.

\section{Las clases sociales}

Las clases sociales han sido distintas en cada civilización: en China eran mandarines los intelectuales y militares los aristócratas, luego estaban los campesinos, los comerciantes, los esclavos y los bárbaros o extranjeros. En el Egipto faraónico, los escribas compartían con los sacerdotes la intelectualidad, los militares también eran la clase alta, siendo los campesinos y esclavos la baja. En la India los brahamanes eran los curas y los sabios, los sutras los agricultores, los vaysias los de la actividad mercantil, los ksatriyas los del ejército y los parias los intocables o sin casta. En el Israel bíblico, los levitas eran los sacerdotes, los amhaarez los esclavos, luego había campesinos, comerciantes, hidalgos, artesanos en gremios asociados y gentiles o extranjeros. En Arabia antigua los ulemas eran los curas, los amma los campesinos, los sagaliva los esclavos, los mawlas los extranjeros, los jassa los militares y también había comerciantes en la la civilización extendida con el islamismo. En el Perú prehispánico o Tawantisuyo o imperio de los cuatro cuartos, los yamas eran los 
intelectuales, los curacas los que se dedicaban a la actividad mercantil, los orejones los hidalgos, los canaris los del ejército y asimismo existían sacerdotes y agricultores. En el México precolonial o imperio del anahuac, los tlacuiloanime eran los intelectuales, los calpullis los curas, los maccahuallis los campesinos, los tamenes los comerciantes, los tlamenes los esclavos, los mayenques los hidalgos, los pipliltin los extranjeros y los pochtecas los militares. En Persia los katuras eran los sacerdotes, los osgaras los campesinos, los anukekis los hidalgos, los sabaysas los aristócratas y también había esclavos. En el Japón antiguo, los samurais eran los hidalgos, los chonin los artesanos, los deinyas los militares y asimismo existían campesinos y esclavos. En la antigua Ghana los dyong eran los esclavos, los horro los hidalgos, los ulusu los herreros y los diali los militares. En Babilonia eran los nobles, los campesinos, los esclavos y los mushkonis o artesanos.

En la Grecia clásica, además de los amos o eupátridas o pedieos y los esclavos o ilotas, campesinos o clerugos u honestiores, según K.Marx (Marx, 1.873), aparte de que ignoraba las clases sociales de las otras civilizaciones, estaban los bibliographoi o escritores, los gorgos o curas, los libertos o antiguos esclavos, los aristoi o diacrios o hidalgos, los metecos o bárbaros y los demiurgos o paralios o artesanos. En Roma los librarii eran los intelectuales, los pontífices los sacerdotes, los homilibres los agricultores, los equites los hidalgos, los plebeyos los artesanos, los patricios los nobles y también había libertos y esclavos, en una proporción mayor, trescientos de media por amo que la Helade, en la cual eran quince. En la Europa medieval los estamentos eran los de los monjes, mitad curas y mitad escritores, con un trece por ciento de la población, los siervos de la gleba con un setenta, los hidalgos o hijos de algo con un tres, los gremios de artesanos con un nueve y los nobles con un cinco. Las clases sociales occidentales de ahora son la alta de los capitalistas, la clase media con con los pequeños burgueses, los intelectuales, los obreros profesionales, restos de aristocracia, del ejército y de la iglesia, y la clase baja de marginados y emigrantes tercermundistas. El proceso histórico ha ido sustiuyendo a unas clases sociales por 
otras, así en la prehistoria los chamanes por los guerreros, en la edad Antigua los amos de los esclavos que, en la edad Media fueron los sacerdotes, en la edad Moderna los burgueses sustituyen a los nobles, en la edad Contemporánea los obreros a los capitalistas en el comunismo y en la era Atómica los homosexuales y las feministas intentan dominar. La cuestión que nos interesa es que no es cierto el determinismo, en tanto y cuanto aniquilación de la libertad humana, por la clase económica, lo que no significa negar su condicionamiento, igual que el sexual, el cultural, el generacional y todos los que se quieran.

Hay cinco espacios de la libertad: el físico, el político, el económico, el higiénico y el moral. La libertad social o general o de información o de comunicación o política o sindical o formal o de circulación es la que nos interesa. Pongamos un ejemplo, la pornografía.¿Tiene derecho la persona a hacer lo que quiera? En el caso de la pornografía, o sea, exhibir imágenes fotográficas, cinematográficas, televisivas, videográficas e informáticas de desnudos eróticos. Desde el punto de vista de la libertad universal no, desde el ángulo de la libertad natural sí y desde el enfoque de la libertad social si y no, sí con reservas, si con excepciones, si a la imagen sexual pero no a la de niños desnudos. La libertad de comunicación ha de permitir iconos eróticos para no caer en un puritanismo inquisitorial, pero no imágenes sexuales de la infancia. La pornografía ha de tener un límite en el campo de la información. La película "El escándalo de Larry Flyn" (LI) dirigida por M.Forman defiende la libertad absoluta para la prensa escrita y audiovisual, no sólo en el caso del sexo, también en el de la violencia, no sólo para lo erótico, asimismo para la agresividad, no sólo para lo pornográfico, igualmente para lo escabrósamente morboso.

Las imágenes pornográficas en videos y por Internet con niños, la pederastia, han de restringirse en el ámbito de la comunicación. Hay que actualizar el pensamiento hegeliano, como reflexiona K.Papaioannou (Papaioannou, 1.981) a la realidad actual. El derecho a la información, no sólo ha de limitarse morálmente, como acabamos de 
exponer, también ha de contenerse éticamente, en tanto y cuanto se refiere al derecho personal de la privacidad, al menos en los cinco espacios: sexual o natural, económico o social, estético o político, positivo o moral e higiénico. El erótico lo hemos expuesto, el espacio físico; el social, el espacio económico, el de los gobernantes y gobernados, la elite y la masa; es decir, como los dirigentes no tienen vida privada, ha de saberse que hacen con los dineros públicos, todo cargo ha de exponer su propiedad al empezar y al acabar su función. Los artistas y seudo que están siempre en las revistas del corazón, tampoco se pueden quejar del agobio periodístico; luego está es el espacio de la ley positiva y el derecho de las masas que no es el de gentes. Delimitemos el quinto espacio, con una verbigracia. Véase el esquema 4 adjunto.

Esquema 4 de la libertad:

ámbito

$$
\text { espacio }
$$

ideología

economía

revoluciones

pensadores

formal - ley natural - liberalismo - capitalismo francesa e inglesa J.J.Rousseau escuela clásica y la ilustración

de fondo - social - $\quad$ socialismo - comunismo rusa y china K.Marx y la izquierda hegeliana

de masas - higiénico - fascismo - nacional socialismo - alemana e italiana .W . Nietzsche y la derecha hegeliana global - político - positivismo - neocapitalismo I.Kant $\quad \mathrm{y} \quad \mathrm{el}$ feminista y gay fenome-ley-positiva-humanismo- socialismoneopositivismo G.W.F.Hegel y el nológica tercermundista existencialismo racial y religosa - 


\section{La libertad}

Pongamos un ejmplo de los cinco espacios de la libertad humana, un vagabundo en el centro de la gran ciudad, un streetman o un clochard. Un pueblo, una pequeña urbe, un barrio popular de la macrópolis o un país subdesarrollado, todavía están en el pasado, el futuro se ve en el presente del centro de un gran burgo. Un vagabundo se tumba en un banco público, en el cual caben cuatro personas sentadas, por lo tanto, ocupa el espacio físico cuadruple de la libertad qe le corresponde. Hasta ahora, en la protohistoria de la humanidad, pues en la prehistoria no había vagabundos, no importaba. La marginación social comienza estrictamente con el desarrollo industrial, en la edad Contemporánea, pues en las edades Antigua, Media y Moderna, no existía, los esclavos, siervos y criados no se iban a vivir a la calle, son los proletarios que se vuelven lumperproletariados, por una cuestión sicológica de desclase social.

El derecho romano, heredero de la filosofía griega clásica y de la jurisprudencia mesopotámica, consideraba que, el ciudadano, era libre, por ello, la ciudadanía se hizo extensiva de Roma a Italia y en el año 212, por el edicto Caracalla, a todo el imperio. En la verdadera historia que comienza ahora, hay un concepto nuevo: la masificación, somos seis mil quinientos millones de individuos. En virtud de lo cual, el espacio físico de la libertad del ciudadano, no todavía del campesino y del tercermundista, ha de ser restringido, un vagabundo no debe tumbarse en un banco público, pues ocupa el espacio de cuatro sujetos. Si ponemos otros ejemplos igual: coches mal aparcados, casas suntuosas (ocupan el espacio de edificios de viviendas), derroche del agua (gastamos en Occidente lavándonos los dientes lo que en el tercer Mundo tienen para beber), los canales televisivos se ponen de acuerdo para colocar los anuncios publicitarios al mismo tiempo y teléfonos móviles en los autobuses u otros lugares públicos, no deben de aguantar los demás la conversación privada. 
El tercer Mundo ya lo estudié (Hernáiz, 1.983: 441 y ss) es la parte pobre de la Tierra, aunque se pueden especificar cinco divisiones: el primer Mundo capitalista, con el $70 \%$ de la riqueza y el 15\% de la población, constituido por 37 naciones muy ricas de Europa, Norteamérica y Japón. Todavía son pobres las 7 antiguas comunistas que han entrado en la Unión europea, por lo tanto, se quedan en 30. El segundo Mundo socialista, con el 5\% de la riqueza y el 30\% de la población, constituido por 6 países pobres comunistas, a los que hay que añadir los 7 anteriores. El tercer Mundo subdesarrollado industriálmente propiamente dicho, con el 10\% de la riqueza y el 35\% de la población, lo forman 138 naciones pobres. El cuarto Mundo hambriento, con el $0 \%$ de la riqueza y el $5 \%$ de la población, constituido por 25 países muy pobres, todos africanos menos Haití. El quinto Mundo desarrollado, con el 15\% de la riqueza y el $15 \%$ de la población, formado por 10 naciones ricas: Australia, N.Zelanda, Omán, Kuwait, Bahrein, E.A.U., Corea N., Singapur, Taiwan e Israel. Véase el esquema 5 adjunto.

Esquema 5 de los Mundos:

Primer Mundo capitalista - 70\% - 15\% - 30 naciones muy ricas.

Segundo Mundo comunista - 5\% - 30\% - 13 pobres.

Tercer Mundo subdesarrollado - 10\% - 35\% - 138 pobres.

Cuarto Mundo hambriento - 0\% - 5\% - 25 muy pobres.

Quinto Mundo desarrollado - 15\% - 15\% - 10 ricas.

El hambre tiene siete causas: las multinacionales pagando las materias primas como quieren, los gobiernos corruptos, las masas analfabetas, las antiguas metrópolis, las 
catástrofes naturales, el subdesarrollo industrial y el lujo capitalista. D.S.Landes (Landes, 1.999) escribe que hay tres clases de países: los que no comen, los que lo hacen y los que se preocupan por el colesterol. Compara los 16 países ricos por su renta per capita. Véase el esquema 4 adjunto. Hay que especificar que España, la cual en el año 1.830 no tenía censo siquiera, desde el año 1.970 ha experimentado la mayor subida, hasta el octavo puesto También que Rusia ha descendido, pasando del segundo al tercer Mundo, a consecuencia de la caida del muro de Berlín y fracaso del comunismo, en el año 1.989. Manuel Castells (Castells, 2.000) hace otro estudio comparando los continentes tercermundistas. Véase el esquema 6 adjunto.

Esquema 6 de las 16 naciones ricas:

U.S.A. 1.830 - 240 dólares - 1.970 - 3.605.

Canadá $\quad 280 \quad 3.005$.

Suecia 235.965.

$\begin{array}{lll}\text { Suiza } & 240 & 2.785 .\end{array}$

Alemania $240 \quad 2.705$.

Dinamarca $225 \quad 2.555$.

Francia $\quad 275 \quad 2.535$.

Noruega $\quad 225 \quad 2.405$

Holanda $\quad 270 \quad 2.385$. 


\begin{tabular}{|c|c|c|c|c|}
\hline Bélgica & 240 & 2.385 & & \\
\hline Gran Bretaña & 370 & 2.225 & & \\
\hline Japón & 186 & 2.130 & & \\
\hline Italia & 240 & 1.670 & & \\
\hline Rusia & 180 & 1.640. & & \\
\hline España & & 1.400. & 2.005 & 12.400 \\
\hline Portugal & 250 & 985. & & \\
\hline
\end{tabular}

Esquema 7 de los continentes del tercer Mundo:

Africa $-1.989-1,8$ campo - 0,2 industria - 1,5 servicios.

$\begin{array}{llll}\text { Asia oriental } & 5,3 & 10,3 & 7,9 \\ & & & \\ \text { “ Sur } & 2,7 & 7,2 & 6,1\end{array}$

$\begin{array}{llll}\text { Iberoamérica } \quad 2,5 & 1,1 & 1,7\end{array}$

Manuel Castells (Castells, 2.000) ha relacionado el tercer Mundo con el tema de la era de la información, sociedad en la que el concepto de la libertad cambia. El espacio 
económico de la libertad nos llevaría al razonamiento, en la verbigracia del vagabundo, que la clase social capitalista goza de mayores privilegios, también la clase social media, por lo tanto, bien puede el mendigo ser dueño de la calle. Llevando el argumento marxista radical al extremo, llegamos a la dictadura del proletariado, mejor dicho, del lumperproletariado, a través de la revolución comunista que acabe con las clases sociales. Volvemos al concepto de la masificación que K.Marx no pudo atisbar en el siglo XIX, es el problema de la centuria XXI. La calle es de todos, para sentarse en los bancos, no aparcar mal los automóviles, no malgastar los recursos hidráulicos, no hacer edificios sobresalientes, no dirigir a las masas publicitáriamente y no charlar descarádamente, a voces y diciendo intimidades, por el teléfono móvil en lugares públicos.

No es cuestión de ricos y pobres, la calidad económica, sino de cantidad de personas. El quinto espacio de la libertad, en el ejemplo del vagabundo, el ámbito higiénico, llena de bolsas de plástico los alrededores del banco público, pues es de su propiedad económica o física, según hemos propuesto anteriórmente, aunque no debe ser así. Además, pues, tiene una carencia de higiene, lo mismo que sus ajadas ropas. La antropología nos enseña que, todo animal, tiene un territorio y que marca sus límites con su olor, a través de la orina, heces y piel restregada en los arbustos. La masificación no puede consentir lo que permite el individualismo liberal, sin que sean necesarias las dictaduras fascista o comunista, imaginemos millones de vagabundos ejerciendo su libertad mal entendida, las pestes medievales serían un juego de niños. La ecología tiene aquí su razón de ser, no sólo para defender los animales y los vegetales.

El quinto espacio de la libertad humana es el ético, si se debe o no hacer algo al respecto. Otro espacio es el estético, siendo el arte la forma de la ética. Mientras los espacios físico, sexual o natural, económico o social e higiénico, son temporales, por su materialidad, la religión es espiritual, en virtud de lo cual, intemporal. En el 
ejemplo del pordiosero, al creerse el dueño del banco público, además de no dejar sentarse a los demás, legal, olorífica y físicamente, saca el pene de sus andrajos y se masturba. Naturálmente es mucho más grave el caso de los pederastas, a través de Internet.

Pero queremos llegar a una conclusión: el individuo es libre pero la masa no, en el más puro sentido hegeliano, como analiza E.Weil (Weil, 1.950), pues el volksgeist o espíritu universal está por encima del sujeto, idea con la que coinciden los marxistas. La masificación, como muy bien vió José Ortega y Gasset (Ortega, 1.997: 45), el aumento de la población, es la rebelión de las masas. El liberalismo del parlamentarismo inglés, la quinta esencia de la democracia moderna, no de la clásica, no es compatible con las autopistas de la información. No es la solución fascista o comunista de la dictadura personal o del partido, pero tampoco el de los clubes de los lores británicos. T.Hobbes (Sabine, 1.974), J.S.Mill (Barber, 1.976), A.Smith (Barber, 1.976), J.Locke (Sabine, 1.974), D.Hume (Sabine, 1.974) y D.Ricardo (Barber, 1.976) no conocieron el progreso tecnológico actual. Además de la economía clásica, la ilustración francesa sigue el mismo camino ideológico, así J.J.Rousseau (Rousseau, 1.981), C.L.Montesquieu (Sabine, 1.974) y A.M.A.Voltaire (Voltaire, 1.999), los cuales provocaron, entre otras causas, las revoluciones inglesas de los años 1.640 y 1.688 y francesas de los años 1.789, 1.830, 1.848 y 1.871.

En tanto y cuanto se refiere a los ámbitos de la libertad, tenemos que, la formal, la de los derechos de asociación política, de manifestación, de prensa, de televisión, de radio, de circulación, de enseñanza, jurídicos de asistencia letrada y presunción de inocencia, producto de la ideología liberal y de la economía clásica inglesa, así como de la ilustración francesa, siendo el concepto de la libertad de tous o générale de J.J.Rousseau (Rousseau, 1.981), su mayor exponente; es la base del sistema capitalista de la propiedad privada de los medios de producción industrial, de servicios y de la agrícola, la libertad natural de Hegel. 
El ámbito de fondo de la libertad, la social, la de los derechos de sindicación, de huelga y de control económico popular, es la ideología socialista, el sistema comunista de las revoluciones rusa del año 1.917, china del año 1.949 y cubana del año 1.959. El concepto lo acuñó K.Marx (Marx, 1.873) y la izquierda hegeliana, la libertad general o de arbitrio. El ámbito de la libertad de las masas, en la ideología fascista y en la economía nacional socialista, llebado a cabo por A.Hitler, en la revolución alemana del año 1.933, B.A.A.Mussolini, en la revolución italiana del año 1.919, y José Antonio Primo de Rivera y Sáenz de Heredia marqués de Estella en la creación de Falange, en el año 1.933. Siguen el pensamiento de F.W.Nietzsche (Nietzsche, 1.982) y la derecha hegeliana, es la libertad universal o absoluta.

El ámbito de la libertad global de la ideología postivista, formulada por C.R.H.Saint Simon (Saint Simon, 1.825) y su secretario A.Comte (Comte, 1.982), es la base del sistema neocapitalista o capitalista avanzado de la sociedad de la información; siguiendo el pensamiento del idealismo alemán de I.Kant (Kant, 1.984), F.Shelling (Gambra, 1.965) y J.Fichte (Gambra, 1.965), revitalizado en la escuela neopositivista de B.Russell (Russell, 1.964) y L.Wittgenstein (Menk, 1.994), así como en la teoría de los valores de M.Scheler (Uscatescu, 1.973) y N.Hartmann (Uscatescu, 1.973). Para M.Scheler, al contrario que para J.J.Rousseau (Rousseau, 1.981), no existe condicionamiento social alguno de la libertad de la conciencia del ser humano.

Por último, el ámbito de la libertad fenomenológica, siguiendo la ideología humanista cristiana y, su mala interpretación en la teología de la liberación o el socialismo tercermundista, vuelve a Hegel en su pureza y en los existencialistas S.Kierkegaard (Uscatescu, 1.983), M.Heidegger (Heidegger, 1.999) y K.Jaspers (Jaspers, 1.968). Los existencialistas franceses A.Camus (Camus, 1.999) y J.P.Sartre (Sartre, 1.960) van por otro camino ideológico, el marxista. G.Gurvitch (Gurvitch, 1.963) analizó las dialécticas ascendentes y descendentes. La cuestión es si, la masa, es libre, independiéntemente del individuo que la compone, el cual lo es a nivel 
formal o derechos ciudadanos o de gentes o ius gentium, de fondo o económicamente, fenomenológicamente o en el plano de la ética o derecho civil de J.Bodino (Sabine, 1.974), saludáblemente o bajo el punto de vista ecológico; en quinto lugar, si tiene derecho a no ser dirigida televisiva, radiofónica, discográfica y cibernéticamente.

Independientemente de todo el pensamiento hegeliano, lo que nos interesa en este artículo es la utopía, es decir, el historicismo; o sea, cuando el final de la historia de la humanidad se convierte en teodicea; o lo que es lo mismo, la reconciliación de Dios con la especie humana, la cual se redime del pecado original (Biblia, 1.960: Génesis) y constituye una ucronía. La metafísica idealista kantiana es convertida en dialéctica idealista hegeliana y, luego, se transforma en dialéctica materialista marxista. El final de la historia convertida en teodicea, ni que decir tiene, no es menester explicarlo, la meta de la historia de la humanidad es Dios; por lo tanto, la sociedad que está fuera del tiempo, es una ucronía o utopía fuera del espacio, como expuse en el XIX Congreso de sociología celebrado en Caracas (Venezuela), el 20 de Septiembre de 2.007. P.Johnson (Johnson, 2.003: 18) escribe textuálmente: “Bajo la influencia de Hegel y sus seguidores, la revolución cristiana y judía, según aparece en la Biblia, fué reinterpretada como un proceso sociológico determinista que partía de la superstición tribal primitiva para llegar a la eclesiología urbana culta". En unos ejes de coordenadas cartesianos, la ordenada es el eje sincrónico, el tiempo, la abcisa es el eje diacrónico, el espacio, y el tercer eje, el sensible; el alma colectiva de la humanidad, el volksgeist o espíritu absoluto o popular o universal. La reconciliación, pues, de ese alma colectiva de la humanidad, tras un desarrollo evolutivo de un proceso sensible, en contradicción dialéctica con las circunstancias, sería la parousia o final de la historia. El alma colectiva es una idea no sólo hegeliana y nacionalista, la derecha hegeliana, es también hindú $\mathrm{y}$, en la cultura occidental, todos los historiadores citados. Véase el esquema 8 adjunto. 
Esquema 8 del alma colectiva:

Tiempo

- Alma colectiva

...Espacio

En la fenomenología hegeliana es la dialéctica del amo y del esclavo, en la conciencia desgarrada que, para el marxismo, será social, la lucha de clases burguesa y proletaria. Sicológicamente, el desdoblamiento de la conciencia, el en sí y el para sí, es la inteligencia y la alienación, la racionalidad y la enajenación, que en el marxismo es laboral; la concreción y la abstracción, el ser y el no ser, el yin y el yang taoista, la acción y la reacción química, el positrón y el electrón físico, la tesis y la antítesis lógica, lo positivo y lo negativo ético, Dios y el Diablo, el ángel custodio y Lucifer, la bondad y la maldad, el amor y el Demonio, el altruismo y el Maligno, la generosidad y el egoismo. El en sí hegeliano es la teoría marxista e izquierda hegeliana, el acto aristotélico, la intuición original de la praxis de E.Mounier (Domenech, 1.973). El para sí hegeliano es la intuición kantiana y el principio de intencionalidad de F.Brentano (Brentano, 1.907). 
Hegel es un fenomenólogo, es decir, un planteamiento dinámico del espíritu, una ciencia del sentimiento, una sícologia emocional y no mental, afectiva y no reflexiva. La fenomenología o ciencia del sentimiento no sólo es hegeliana, tambien de J.M.P.Teilhard de Chardin (Teilhard, 1.967), E.Husserl (Husserl, 1.933) y M.Ponty (Gambra, 1.965). La metafísica y la lógica formal escolástica aristotélica son estáticas, mientras que la dialéctica hegeliana marxista es dinámica, lo que ocurre es que la fenomenología es idealista y el socialismo materialista. Hegel no inventa la dialéctica, claro es, ya está en el pensamiento dinámico de L.Tsé (Ling, 1.968), G.S.Buddha (Schweitzer, 1.935), Zenón de Elea o Citio (Tatarkiewicz, 1,987), Heráclito de Clio el Oscuro (Tatarkiewicz, 1.987) y los neoplatónicos Filón (Tatarkiewicz, 1.987), Proclo (Tatarkiewicz, 1.987) y Plotino (Tatarkiewicz, 1.987); donde la tesis es la unidad o moné, la antítesis la dualidad o prohodos y, la síntesis, la vuelta sobre sí mismo o epistrophé. Para el taoismo (Ling, 1.969) el uno se convierte en dos, o sea, el orden en el caos y, entre ambos, nace el tres, es decir, la armonía. Para la escolástica y sus 21 principios lógico formales, algunos combatidos por las leyes dialécticas: la de la acumulación de lo cuantitativo dando un salto cualitativo, el de finalidad; la de la síntesis (de la tesis y de la antítesis) o de la totalidad, el del tercero excluido; la de la oposición antitética o de la lucha de contrarios, el de no contradicción, la del cambio o la de la realidad y la necesidad, el de la razón suficiente, el de la causa eficiente y el de analogía; la de interacción (de causas y efectos) o de la conexión universal, el de causalidad.

\section{La lógica}

La filosofía escolástica es un conjunto de 21 normas lógicas: el principio de identidad $(\mathrm{A}=\mathrm{A})$, el principio de transitoriedad $(\mathrm{A}=\mathrm{B}, \mathrm{B}=\mathrm{C}$, luego $\mathrm{A}=\mathrm{C})$, destacando el silogismo o razonamiento de Aristóteles; el principio de reciprocidad $(A=B$, luego $\mathrm{B}=\mathrm{A}$ ), el principio del todo mayor que la parte, el principio de causalidad (a toda causa un efecto), el de la causa material aristotélico así como los tres siguientes, el de 
la causa eficiente, el de la causa final, el de la causa formal, el de conmutación $(\mathrm{A} \times \mathrm{B}=\mathrm{B} \times \mathrm{A})$, el de participación (A se incluye en $\mathrm{B})$,

el de la verdad o mentira de un enunciado criticado por el neopositivismo lógico de B.Russell (Russell, 1.964) con el catálogo de una biblioteca que es un libro que paradójicamente no se incluye a sí mismo y L.Wittgenstein (Menk, 1.994) con el pato que parece un conejo; el de finalidad, el de no contradicción formulado por Aristóteles o del tercero excluido (A es o no es A) combatido por la síntesis dialéctica de la tesis y de la antítesis o de la totalidad; el de resonancia, el de complementareidad, el de analogía, el de figuración (que la explicación total de los términos se ordenan), el de incertidumbre aplicado por la física moderna pues no se sabe si la luz va por ondas o por rayos, el de globalidad lo reelaborarían B.Pascal (Gambra, 1.965), G.G.Leibniz (Gambra, 1.965) y E.Durkheim (Gambra, 1.965), el de la causa eficiente y el de razón suficiente tambien aristotélicos. El método dialéctico es el de la síntesis tras el análisis. Lo indefinido es la síntesis de lo finito y de lo infinito, escribe Hegel y también, entre la verdad y la mentira está lo indefinido.

Para quien piense que, lo precedente, es pura teoría, pongamos un ejemplo práctico: la derecha política es el orden social, la izquierda es la libertad y, la síntesis, el estado de derecho. Aristóteles (Sabine, 1.974) ya explicó que: el título de poder de la aristocracia es el orden y el de la democracia la libertad, aunar ambos conceptos, para impedir la tiranía y la anarquía, es la sociedad mixta ideal. Las cuatro escuelas griegas clásicas del pensamiento: la Academia de Platón (Tatarkiewicz, 1.987) idealista, el Liceo de Aristóteles (Tatarkiewicz, 1.987) realista, el Jardin de Epicuro (Tatarkiewicz, 1.987) materialista y la Stoa de Zenón de Elea (Italia) (Tatarkiewicz, 1.987) idealista extrema, se repiten en la Alemania ilustrada: idealismo de I.Kant (Kant, 1.800), realismo de Hegel (Hegel, 1.829), materialismo de K.Marx (Marx, 1.873) e idealismo extremo de F.W.Nietzsche (Nietzsche, 1.982). La derecha hegeliana es: Nietzsche, A.Schopenhauer (Gambra, 1.965), Renán (Gambra, 1.965), D.F.Strauss 
(Gambra, 1.965) el nazismo y el fascismo, la izquierda es L.Feuerbach (Gambra, 1.965), B.Bauer (Gambra, 1.965), M.Stirner (Gambra, 1.965), F.Engels (Engels, 1.964), K.Marx (Marx, 1.873), el socialismo y el comunismo, el cual la sintetiza con la izquierda saintsimoniana (Saint Simon, 1.825), en el materialismo dialéctico o diamat, criticando el idealismo dialéctico o realismo hegeliano y el idealismo kantiano. Se puede objetar que, las cuatro formas de pensamiento, en el esquema 2 son cinco, pero el liberalismo inglés es otra variante del idealismo alemán. I.Kant (Kany, 1.800) definió al siglo de las luces de la ilustración francesa como: el fin de la minoría de edad del ser humano y su conciencia de culpa debido al pecado original.

\section{I.Kant}

I.Kant (1.724 - 1.804) nacido y muerto en Königsberg (Alemania), pues nunca se movió de allí, no viajó a parte alguna y todos los días hacía lo mismo y a igual momento, de tal manera que, sus vecinos, sabían que hora era cuando él pasaba. Sus libros principales de los cuarenta y dos escritos son: "Crítica de la razón pura", “Crítica de la razón práctica” y “Crítica del juicio”. Es un romántico ilustrado y republicano. La "Crítica de la razón pura" no se publicó hasta el año 1.871 y en ella critica la demostración a priori de Dios u ontológica y la a posteriori o cosmológica. P.Francastel (Francastel, 1.970: prólogo) escribe que, cuando se murió su criado, los amigos no sabían cómo resolver el problema, pues uno nuevo no conocía el orden perfecto de todas las cosas de su casa. Cuando alguien le visitaba, aún cuando ya estaba enfermo, en su ancianidad, no se sentaba hasta que el visitante no lo hiciera.

Según Rafael Gambra (Gambra, 1.965) sintetiza racionalismo y empirismo, la teoría y la práctica, los juicios pueden ser analíticos y sintéticos, los primeros existen a priori, así la sensibilidad externa es un a priori de la realidad, la interna de la conciencia, por ello Hegel (Hegel, 1.807) dirá que, el ser sensible, es más real; mientras que los juicios sintéticos son deducciones del tipo de que, la Tierra, gira alrededor del Sol, no está en 
la esencia de nuestro planeta, el razonamiento es nuestro, no el movimiento del Globo azul. La ciencia y la filosofía, demostración y mostración de la realidad respectívamente, han de ser analíticos y sintéticos sus juicios, esa es su necesidad. La otra cualidad es la del proceso evolutivo. La ciencia y la filosofía son la razón y querer: pura o matemática, física y metafísica. Los juicios pueden ser, según su cantidad: universales, singulares y particulares, categorías kantianas de: totalidad, pluralidad y unidad; según su cualidad: afirmativos, negativos e indefinidos, afirmación, negación y limitación; según su relación: categóricos, hipotéticos y disyuntivos, substancialidad, causalidad y reciprocidad; y según su modalidad: asertóricos, apodícticos y problemáticos, realidad, probabilidad y necesidad.

La razón es la facultad del conocimiento, la ilustración y la libertad son las metas de la razón, la filosofía es también ciencia, para Kant, la de la relación de todos los conocimientos a los fines esenciales, de la razón humana. En "La crítica de la razón pura" plantea a la metafísica como ciencia, en tres fases: estética, analítica y dialéctica. Los conceptos del entendimiento son empíricos y categorías, las cuales se clasifican por: cantidad, cualidad, relación y modalidad. El nóumeno es la esencia o causa hipotética de los fenómenos. En "La crítica de la razón práctica" se ocupa de la moral, donde cree que, las éticas, son heterónomas porque establecen fines, son empíricas e imperativas. La ética debe ser universal y racional. En "La crítica del juicio" habla de estética, de religión y de dialéctica. La sensibilidad puede ser un a priori externo o percepción sensorial y un a priori interno o creador. Criticó a Aristóteles porque su lógica u “Organon", era una relación de categorías por su esencia, accidentes y entidad de género y especie. El imperativo categórico de la conciencia es su principal tesis, la obligación moral del ser humano a hacer el bien. Conocer, hacer y esperar son las tres fases de la praxis humana. Cristiano protestante planteó que, nadie puede discutir la existencia humana de Nuestro Señor Jesucristo, otra cosa es la divinidad pero, además, el problema que fué hace veinte siglos, 
entonces dieciocho, por lo tanto, la presencia real se confunde con el mito, el acontecimiento con la leyenda, la historia con la story.

La película "La mancha humana" (LII) dirigida por S.Coleman e interpretada por A.Hopkins y la guapa N.Kidman nos plantea el tema de lo políticamente correcto, tal como expuse (Hernáiz, 2.004) un profesor de una universidad norteamericana expulsado por racista, cuando él era negro y amigo de ellos, pero se expresó mal. Esa es la alienación absoluta, el no poder hablar, pues a un negro hay que decir que es persona de color, a un homosexual que es gay, a un preso que es un individuo interno, a un minusválido que no lo es, etc.

La mayor tiranía no es la fascista ni la comunista, es la de la conciencia mediática, la de no poder decir nada más que lo políticamente correcto, la que ordena los medios de comunicación de masas o mass media, la quinta de nuestro esquema 2. La tecnotesis en una tecnodialéctica, amplía las dos dimensiones de la tesis y de la antítesis, para conseguir la síntesis dialéctica o dinámica. Carlos Díaz Hernández (Díaz, 1987: 12 y 14) dijo que Hegel vale para todos y, M.Clavel (Díaz, 1987: 16 y 55) que era un problema de sintaxis. S.Kierkegaard (Díaz, 1.987: 60 y 67) que, el peor castigo para un alumno, es mandarle leer a Hegel. Marcelino Menéndez Pelayo (Díaz, 1.987: 68 y 71) afirmó que en España no existió. Xavier Zubiri (Díaz, 1.987: 72 y 73) que es la consumación intelectual de Occidente. Ramiro Florez (Díaz, 1.987: 80 y 81) que, la derecha política, busca la historia y, la izquierda, la razón. H.Marcuse (Díaz, 1.987: 82 y 85) que, el día que A.Hitler ganó las elecciones en Alemania, se acabó Hegel. V.I.U.Lenin (Díaz, 1.987: 89 y 93) que, el idealismo, es un materialismo al revés, como he dicho de K.Marx en los congresos XX de sociología iberoamericana en Santiago de Chile el 15 de Septiembre de 2.008 y en Valencia el 2 de Diciembre de 2.008. José Ortega y Gasset (Díaz, 1.987: 94 y 104) que es el que introdujo el concepto de evolución en la filosofía, aunque no entendía la biológica. La conciencia es el pensar y, el pensamiento, es la substancia general del espíritu. Hegel, al contrario que 
B.Espinoza, no creyó que, el pensamiento y el espíritu, estuvieran en relación de atributo y substancia.

Explicó como, lo racional y lo sensible, son más real. La realidad no está hecha, es sólo lo que se hace. Para el salto de una categoría a otra se han necesitado milenios. El tiempo es la cuarta dimensión de lo real, como afirmó T.W.Adorno (Díaz, 1.987: 108 y 110). La realidad es circular. Dios es el movimiento hacia lo infinito. Si la libertad individual no existe, es necesario lo racional como substancia. B.Russell (Díaz, 1.987: 111 y 131) dijo que el Dios de Hegel es el de un profesor. Díaz afirmó (Díaz, 1.987: 133 y 141) que está en la lucha de claes marxista, en todo F.W.Nietzsche y en la conflictiva relación del existencialismo. Hegel superó el romanticismo, no se perdió en él como J.W.Goethe. El derecho, para I.Kant (Kant, 1.984), es la limitación de la libertad, mientras que para Hegel es la libertad como idea. El que tiene libertad quiere más libertad, puesto que es el en sí y el para sí. J.W.Goethe señaló (Díaz, 1.987: 148) que debe haber alguna limitación. Vivir eticamente es ir avanzando hasta la antítesis del mal. La libertad es la substancia de la eticidad. Los franceses dicen vie ethique, los ingleses ethical life, los italianos eticita y los alemanes sittlichkeit. La libertad subjetiva comienza con R.Descartes, así lo propuso José Ortega y Gasset (Díaz, 1.987: 171, 172, 173 y 174) frente a Miguel de Unamuno y Jugo. Quien dice Europa dice eticidad. La burocracia es una unidad de destino en lo universal. Cada clase social tiene una forma de eticidad. El campesinado es obediente. La burguesía trabaja con honestidad, no creyó Hegel que era una prostituta como pensó W.Shakespeare (Díaz, 1.987: 185, 188 y 189).

La opinión pública es seducida. La historia se mira en las agujas de las catedrales góticas. La voluntad objetiva es lo racional. Una idea es como un ser viviente, pero como dijo José Ortega y Gasset (Díaz, 1.987: 190 y 191) hay ideas creencia y ocurrencia, se refería Hegel a la primera clase, por eso le denominó el emperador del pensamiento, el filósofo de la libertad. Lo racional en sí y para sí es el espíritu de la 
realidad, lo racional es para servir a la persona no al revés. La historia de la humanidad es el espíritu absoluto o el alma colectiva o el volksgeist o el espíritu popular, siendo Dios el fin de la historia y Su paso por la Tierra. Miguel de Unamuno y Jugo (Díaz, 1.987: 197) era hegeliano en su concepto de intrahistoria, pues afirmó que nada había genial sin pasión y el alargamiento de lo humano es lo contrario de la restricción divina de lo humano. E.Fromm explicó (Fromm, 1.947: 50, 84, 89 y 91) que, la existencia humana, va unida a la idea de libertad, la irracionalidad no puede desaparecer hasta que el ser humano no progrese de la libertad negativa a la positiva, es decir, estar solo y privado de seguridad y ser libre de pensar y obrar con independencia; también que la voluntad es libre y que M.Lutero, en contra de Erasmo de Rotterdam, no creyó en el libre arbitrio.Asimismo que tanto en Kant como en Hegel su tema principal era el de la libertad. El embotamiento de la capacidad de pensar críticamente es más peligroso para la democracia que los ataques directos.

Como he explicado en el tema de la conciencia mediática, dice E.Fromm (Fromm, 1.947: 139, 140, 145 y 290) que, un locutor de televisión pasa instantaneamente de la noticia de una matanza de muchas personas al anuncio de la venta de un jabón. Como he dicho en el Instituto universitario teniente general Manuel Gutiérrez Mellado, el 20 de Mayo de 2.009, el espíritu absoluto hegeliano es la globalización cultural, no la económica de las multinacionales, ni la militar de la O.T.A.N. u organización del tratado del Atlántico Norte o nato en inglés, ni la jurídica de la O.N.U. u organización de las naciones unidas, ni la conciencia mediática de Internet, televisión y demás medios de comunciación de masas o mas media. Ya escribió Hegel, al intentar dar sentido a la historia de la humanidad desde la nostalgia que, como en el caso de la masonería, al pretender ocultarlo todo, es posible que no haya nada detrás (Hege1, 1.822: 53) y cuando el buho de Minerva levanta el vuelo, empieza el anochecer. 


\section{Bibliografía}

ADORNO, Teodor.W.: “Tres estudios sobre Hegel”, Madrid, 1.969, Taurus.

ALTHUSSER, Luis: “Pour Marx”, París, 1.969, Masperó.

ARON, Raimond: "Ensayo sobre las libertades", Madrid, 1.991, Alianza.

ASIMOV, Isaac: “Los egipcios", Madrid, 1.986, Alianza.

BARBER, W.J.: “Historia del pensamiento económico”, Madrid, 1.976, Alianza.

Biblia, B.Aires, 1.960, Sociedades bíblicas.

BARTHES, R.: “Lo obvio y lo obtuso”, Barcelona, 1.988, Paidós.

BAUDRILLARD, J.: “Cultura y simulacro”, Barcelona, 1.984, Kairós.

BLOOM, Harold: “El canon occidental”, Barcelona, 1.995, Anagrama.

BRENTANO, Fran: “Sicología de los sentidos", Florencia, 1.907.

BRIGGS, A. y otro: “De Gutenberg a Internet”, Madrid, 2.002, Taurus.

CABRERA INFANTE, Guillermo: “Así en la paz como en la guerra”, Madrid, 1.971, La montaña mágica.

CAHN, A.: “Goethe, Schiller y la época romántica”, B.Aires, 1.970, Nova. 
CAMUS, Albert: “La peste, Madrid”, 1.999, U.Editorial.

CASTELLS, Manuel: “La era de la información”, Madrid, 2.000, Alianza, tres tomos.

CHONSKY, N.A.: “El conocimiento del lenguaje”, Barcelona, 1.994, Atalaya.

COMTE, Augusto: "La física social”, Madrid, 1.980, Aguilar; Catecismo positivista, Madrid, 1.982, Nacional; “Discurso sobre el espíritu positivo”, Madrid, Alianza.

CROWLEY, D. y otros: “La comunicación en la historia”, Barcelona, 1.997, Bosch.

DIAZ, Carlos: “El sueño hegeliano del estado ético”, Salamanca, 1.987, S.Esteban.

DOMENECH, J.: “Mounier según Mounier”, Barcelona, 1.973, Laín.

ENGELS, Federico: “Origen de la propiedad privada, la familia y el estado”, B.Aires, 1.964, Claridad.

FRANCASTEL, Pierre: “Etudes de sociologie de l'art”, Paris, 1.970, Denël.

FROMM, Eric: “El miedo a la libertad”, Barcelona, 1.947, Paidós.

GALBRAITH, John K.: “La era de la incertidumbre”, Barcelona, 1.982, P.Janés.

GAMBRA, Rafael: “Historia sencilla de la filosofía”, Madrid, 1.965, Rialp.

GURVITCH, George: “La vocación actual de la sociología”, París, 1.963, P.U.F. 
HEGEL, Guillermo, Wilheim Federico: 1.801, La lógica de Jena, Fé y razón; 1.802, Relación del escepticismo con la filosofía, Diferencia entre los sistemas de Fichte y Schelling, La constitución de Alemania; 1.807, Fenomenología del espíritu; 1.812, Ciencia de la lógica; 1.820, Enciclopedia de las ciencias de la filosofía; 1.821, Filosofía del derecho; 1.822, Lecciones de la filosofía de la historia; 1.822, Lecciones de la historia de la filosofía; 1.827, Filosofía de la naturaleza; 1.828, Lecciones de la filosofía de la religión; 1.829, Estética.

HEIDEGGER, Martín: “El concepto del tiempo”, Madrid, 1.999, Trotta.

HERNAIZ BLAZQUEZ, Juan Ignacio: “Ideologías tercermundistas actuales", Madrid, 1.983, Universidad Complutense.

HERNAIZ BLAZQUEZ, Juan Ignacio: “Introducción a la sociología del arte", Madrid, 1.985.

HERNAIZ BLAZQUEZ, Juan Ignacio: “Teoría, historia y sociología del arte", Madrid, 1.986, Prensa y ediciones iberoamericanas.

HERNAIZ BLAZQUEZ, Juan Ignacio: “Sociología del amor", Madrid, 1.987, Prensa y ediciones iberoamericanas.

HERNAIZ BLAZQUEZ, Juan Ignacio: “El destino”, Madrid, 1.988.

HERNAIZ BLAZQUEZ, Juan Ignacio: “Keops Kane”, Madrid, 1.996, Prensa y ediciones iberoamericanas.

HERNAIZ BLAZQUEZ, Juan Ignacio: “Historia de la comunicación social: de 
Altamira a Parque Jurásico", Madrid, 1.999, Universitas.

HERNAIZ BLAZQUEZ, Juan Ignacio: “Los ojos de Velázquez”, Madrid, 2.004, Imagine.

HERNAIZ BLAZQUEZ, Juan Ignacio: “Historia de la comunicación: del tintero a Internet", Madrid, 2.007, Universitas.

HURSSEL, Edmund: “Fenomenología trascendental”, Friburgo, 1.933.

HUXLEY, Aldous: “Un mundo feliz”, Barcelona, 1.962, P.Janés.

JASPERS, Karl: “Origen y meta de la historia”, Madrid, 1.968, R.Occidente.

JONHSON, Paul: “Historia de los judíos”, Bogotá, 2.003, Vergara.

KANT, Inmanuel: “Crítica de la razón pura”, Madrid, 1.984, Alfaguara.

KAUFMANN, W.: “Hegel”, Madrid, 1.968, Alianza.

KIERKEGAARD, Soren: "El concepto de la angustia", Paría, 1.955, Gallimard, Journal.

LANDES, D.S.: “La riqueza y la pobreza de las naciones”, Barcelona, 1.999, Crítica, págs. 17 y ss.

LING, Trevor: “Las grandes religiones de Oriente y Occidente”, Madrid, 1.968, Istmo, dos tomos. 
MARCUSE, Herbert: “Razón y revolución”, París, 1.967, Denoël.

MARTIN PROHARAN, Miguel Angel: “La organización de la producción en el cine y en la televisión", Madrid, 1.985, Forja.

MARX, Karl: 1.841, “Diferencia de la filosofía de Epicuro y Demócrito”; 1.843, Textos

sobre la producción artística, La cuestión judía; 1.844, Anales francoalemanes, La sagrada familia, Manuscritos de economía y filosofía; 1.845, La ideología alemana; 1.847, Miseria de la filosofía; 1.848, El manifiesto comunista, Reivindicaciones del partido comunista en Alemania; 1.849, Trabajo asalariado y capital; 1.852, El 18 de Brumario; 1.854, Revolución en España; 1.859, Crítica de la economía política; 1.871, la guerra civil en Francia; 1.872, Historia de la diplomacia del siglo XVIII, Anti Düring, Crítica al programa de Gotha; 1.873, El capital, tres tomos.

MATTELART, A.: “La internacional publicitaria”, Madrid, 1.990, Fundesco.

MAY, R.: “Cine y television”, Madrid, 1.959, Rialp.

MAYNARD, R.: “The major works of S.Freud”, Chicago, 1.987, E.Británica.

MC LUHAN, Herber Marsal: “Comprender los medios de comunicación”, Barcelona, 1.960, Paidós.

MELLERS, William: “Los creadores de imagen”, Barcelona, 1.985, Planeta.

MENK, R.: “L.Wittgenstein”, Barcelona, 1.994, Anagrama.

MONTANELLI, Indro: “Historia de los griegos”, Barcelona, 1.963, P.Janés. 
NIETZSCHE, Federico, W.: “El anticristo”, Madrid, 1.982, Busma.

ORTEGA Y GASSET, José: “La rebelión de las masas”, Madrid, 1.997, Alianza.

ORTEGA Y GASSET, JOSÉ: “Papeles sobre Velázquez y Goya”, Madrid, 1.987, Alianza.

ORWELL, George: “1.984”, Londres, 1.948.

PAPAIOANNOU, K.: “Hegel”, Madrid, 1.981, E.D.A.F.

PEREZ ORNIA, José Ramón: “El arte del vídeo”, Barcelona, 1.9991, Serbal.

PLEBE, A.: “Hegel”, Madrid, 1.976, Doncel.

POPPER, Karl R.: “La sociedad abierta y sus enemigos”, Londres, 1.955.

RODRIGUEZ BAJON, Miguel Angel: “El candidato muerto", Barcelona, 1.998, P.Janés.

ROUSSEAU, Juan Jacobo: “El contrato social”, Madrid, 1.981, E.Calpe.

RUSSELLL, Bertrand : “La sabiduría de Occidente”, Madrid, 1.964, Aguilar.

SABINE, George, H.: “Historia de las ideas políticas”, México, 1.974, F.C.E.

SAINT SIMON, Claude Rourier Henri: 1.802, Cartas de un habitante de Ginebra a sus contemporáneos; 1.804, A los ingleses y a los franceses que son celosos del bien común, Apuntes de un filántropo para un nuevo plan de organización social, Cartas 
a los europeos; 1.807, Introducción a los trabajos científicos del siglo XIX; 1.808, Historia de mi vida, Carta a la oficina de las longitudes; 1.810, Apunte a una nueva enciclopedia, Proyecto de enciclopedia, Memoria sobre la enciclopedia; 1.811, Memoria del hombre, Correspondencia con M.Rodern; 1.813, De la fisiología aplicada al mejoramiento de las instituciones sociales, Trabajo sobre la gravitación universal, Nueva enciclopedia, Memoria sobre la ciencia del hombre; 1.815, Opiniones a tomar sobre las medidas de la coalición, Profesión de fé, De la reorganización de la sociedad europea; 1.816, La industria; 1.818, Cartas a un americano, Visión de la propiedad, Nacimiento del cristianismo; 1.819, Acerca de la querella de las abejas y de los zánganos, El partido nacional, El organizador; 1.820,Carta a los señores jurados; 1.821, Del sistema industrial, Enredos sobre la miseria del proletariado, Canto a los industriales; 1.822, Carta a los señores obreros; De los Borbones y de los Estuardos; 1.823, Catecismo de los industriales, Mesianismo judeocristiano, Del platonismo al cristianismo; 1.825, De la fisiología social, Algunas opiniones filosóficas, Trabajo sobre la organización social, El nuevo cristianismo, Opiniones.

SARTORI, Giovanni: "El homo videns, la sociedad teledirigida", Madrid, 1.998, Taurus.

SARTRE, Jean Paul: “Crítica de la razón dialéctica”, París, 1.960.

SPENGLER, Oswald: “La decadencia de Occidente”, México, 1.934, F.C.E.

SCHWEITZER, Albert: “El pensamiento de la India”, México, 1.935, F.C.E.

TATARKIEWICZ, W.: “Historia de la estética”, Madrid, 1.987, Akal. 
TEILHARD DE CHARDIN, José María Pedro: “El porvenir del hombre”, Madrid, 1.965, Taurus; "El medio divino", Madrid, 1.966, Taururs; Himno al Universo, Madrid, 1.967, Taurus.

TERCEIRO, J.B.: “Sociedad digital”, Madrid, 1.996, Alianza.

TOFFLER, A.H.: “La tercera ola”, Barcelona, 1.986, P.Janés.

TOMAS DE AQUINO, Santo: Sentencias, 1.254; De veritate, 1.256; Los nombres divinos, 1.260; Summa, 1.265.

TOYNBEE, Arnold Joseth: “Estudio de la historia”, Madrid, 1.970, Alianza.

USCATESCU, George: “Agustín, Nietzsche, Kierkegaard”, Madrid, 1.983, Forja.

USCATESCU, George: “Breve teoría e historia de la cultura”, Madrid, 1.973, Reus.

VICO, Juan Bautista: “Ciencia nueva”, B.Aires, 1.981, Aguilar.

VOLTAIRE, Augusto Maria Anuet: “Cartas filosóficas”, Madrid, 1.999, Alba.

WEBER, Max: “Economía y sociedad”, México, 1.964, F.C.E.; “Etica protestante”, Madrid, 1.999, Albor.

WEIL, E.: “Hegel y el estado”, B.Aires, 1.950, Nageleop.

YATES, F.A.: “G.Bruno y la tradición hermética”, Barcelona, 1.983, Ariel.

Volver a la bibliografía Volver al principio del artículo Volver al principio 


\section{Filmografía}

Fahreneit 451, F.Truffaut, 1.966.

Blade runner, R.Scott, 1.982.

Los diez mandamientos, C.B. De Mille, 1.956.

1.984, M.Radford, 1.984.

El show de Truman, P.Weir, 1.998.

Historias para no dormir, la televisión, N.I.Serrador, 1.975.

Historias de la televisión, J.L.S.Heredia, 1.965.

Bienvenido Mr.Chance, H.Ashby, 1.979.

Permanezca en sintonía, P.Hyams, 1.992.

Network, un mundo implacable, S.Lumet, 1.976.

Quizshow, R.Redford, 1.996.

Al filo de la noticia, J.L.Brooks, 1.987.

Cortina de humo, B.Levinson, 1.997.

Ed.Tv, R.Howard, 1.999. 
Tootsie, S.Pollack, 1.982.

Ginger y Fred, F.Fellini, 1.985.

Zaping, ChCarbajosa, 1.999.

Héroe por accidente, S.Frears, 1.992.

Gary Cooper que estás en los Cielos, P.Miró, 1.981.

Pleasentville, G.Ross, 1.999.

Muertos de risa, A.Iglesia, 1.998.

Empieza el espectáculo, B.Fosse, 1.979.

Mad city, C.Gabras, 1.999.

Una rubia peligrosa, M.Allegret, 1.958.

El hombre de la Luna, M.Forman, 2.000.

Un rostro en la multitud, E.Kazan, 1.964.

2.001, una odisea del espacio, S.Kubrick, 1.968.

1.997, rescate en N.York, J.Carpentier, 1.981.

2.013, rescate en Los Angeles, J.Carpentier, 1.996. 
Amor y muerte en Long Island, R.Kwietniowski, 1.997.

El ojo público, H.Frankin, 1.992.

Todos los hombres del presidente, A.J.Pakula, 1.976.

El precio de la libertad, B.Ray, 2.005.

Ciudadano Kane, G.O.Welles, 1.941.

Scoop, W.Allen, 2.006.

Pi, D.Aronosfky, 1.998.

Requiem por un sueño, D.Aronosfky, 2.000.

Juez Dreep, D.Cannon, 1.995.

Tienes un email, N.Epron, 1.998.

Quince minutos, N.Ephron, 1.998.

Buenas noches y buena suerte, G.Clooney, 2.005.

Historias de la radio, J.L.S.Heredia, 1.995.

Días de radio, W.Allen, 1.987.

Sueños de seductor, H.Ross, 1.972. 
Seduciendo a un extraño, J.Fillet, 2.007.

Retrato de una obsesión, S.Shainberg, 2.007.

Intimo y personal, J.Avnet, 1.996.

Inteligencia artificial, S.Spielberg, 2.001.

Acoso, B.Levinson, 1.994.

Red, I.Winkler, 1.995.

El escándalo de Larry Flyn, M.Forman, 1.996.

La mancha humana, S.Coleman, 2.003.

\section{Webgrafía}

HERNAIZ BLAZQUEZ, Juan Ignacio: Lo políticamente correcto, Revista electrónica Hispanidad, 2 de Marzo de 2.004. 